
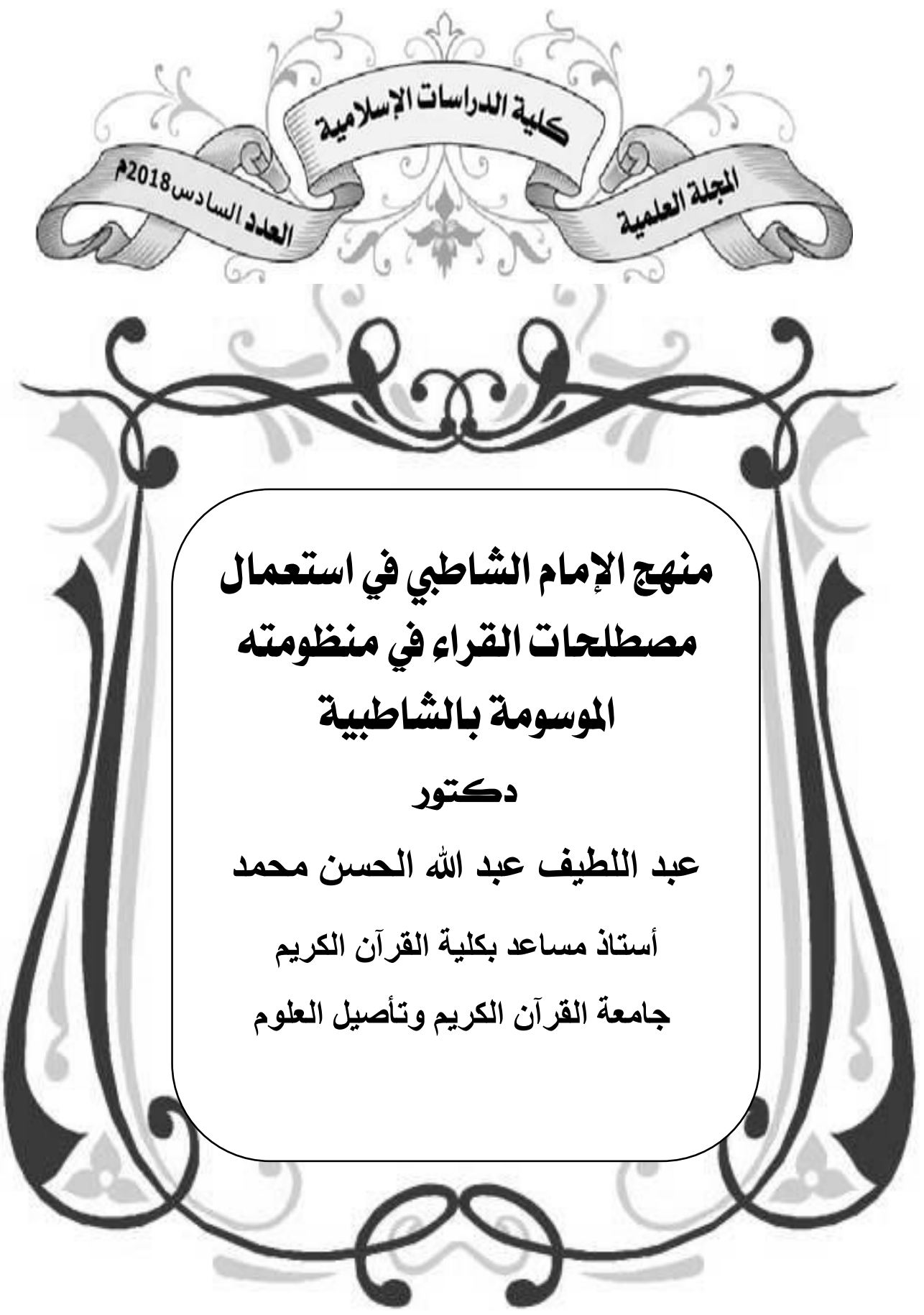


\section{مستخلص البحث}

تهدف الدراسة الكثف عن منهج الإمام الشاطبي في استعمال مصطلحات القـراء فـي منظومتــه الموسـومة بالثـاطبية؛ بغيـة الوصــول إلـى فهـم هـذه المصطلحات، والوقوف على مراده منها، وذلك أنّ كثيراً من تلك المصطلحات تدل على معان اصطلح عليها القراء، ولكنها قد ترد للدلالة على معان أخرى ربما تخفى دلالتها على البعض، إمّا لقلة الاستعمال، أو عدم الاشتهار ؛ فلذا كان توضيح منهج الإمـام الثاطبي في استعمال هذه المصطلحات مهماً من حيث أنّه يفصح عن مراد الناظم، ويسهم في توضيح معنى النظم.

اتبع الباحث المنهج الاستقرائي، والمنهج الوصفي، واشتمل البحث على: مقدمة، وتمهيدٍ، وسبعة مباحث، وختم البحث بخاتمة كان من نتائجها: أنّ الناظم يستعمل التسهيل للدلالة علي معنيين هما: ( ) إبدال الهمز حرف مد، وتسهيلها بين بين r مطلق التغيير في الهمز، كما أنّه في موضع أطلق الترقيق وأراد به الإمالـة، وأطلق التقخيم وأراد بـه الفتح الذي هو عكس الإمالـة، وفي بعض المواضـع استعمل المد وأراد بـه إثبات الألف، واستعمل القصر وأراد بـه حذف الألف، وهذا كثير في نظمـه، كمـا أنسه في مواضـع أطلق الإخفـاء وأراد بـه اختلاس حركة هاء الضمير ، وفي موضع أراد به الإسرار بالقراءة.

وأوصسى الباحـث بدراسـة منظومـة الثـاطبية للاسـتفادة منهـا في الجوانـب العلميـة التي حوتهـا، وتثـجيع البحـوث العلميـة التي تعنـى بجانـب القـراءات ونشرها لتعم فائدتها. 


\section{مقدمة}

الحمد لله الذي اختص هذه الأمة بإرسال خير رسله، وشرفها بإنزال أفضل كتبه، ثم الصلاة والسلام على سيدنا محمد الرحمة المهداة، وعلى آله، وصحبه، ومن تبعهم بإحسان إلى يوم الدين.

فقد جاء هذا البحث دراسـة لمنهج الإمـام الثـاطبي في طريقة استعماله

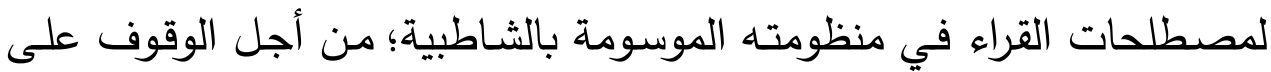
هذه المصطلحات ومعرفـة مدلولها حسب استعمال النـاظم لها؛ لتكون عونـاً لللارس في فهم المنظومة، والإسهام في توضيح معناها.

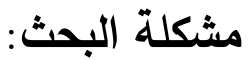
مشكلة البحث: منهج الإمام الثشاطبي في استعمال مصطلحات القراء من خلال منظومته الموسومة بالثاطبية. أما حدود المشكلة فهي تحديد هذا المنهج، والاستفادة منه في توضيح معنى بالنياطي

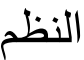

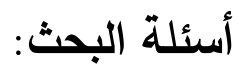

يجيب هذا البحث على السؤال التالي: مـا هو منهج الإمـام الثـاطبي في استعمال مصطلحات القراء من خـلال منظومته الموسومة بالثاطبية. ؟ ويتفرع عن هذا السؤال الأسئلة التالية: 
ما هو منهج الإمام الشاطبي في استعمال التسهيل والتحقيق؟

ما هو منهج الإمام الثاطبي في استعمال التغليظ والترقيق؟

ما هو منهج الإمام الثاطبي في استعمال المد والقصر؟

مـا هـ مـنهج الإمـام الثـاطبي في اسـتعمال الإظهـار والإدغـام والإقـلاب

$$
\text { والإخفاء؟ }
$$

ما هو منهج الإمام الشاطبي في استعمال الفتح والإمالة والتقليل؟

ما هو منهج الإمام الشاطبي في استعمال الروم والإشمام والاختلاس؟

ما هو منهج الإمام الشاطبي في استعمال الوقف والسكت؟

أهداف البحث:

يهدف هذا البحث إلى دراسـة منهج الإمـام الثـاطبي في طريقة استعماله

لمصطلحات القراء في منظومته الموسومة بالشـاطبية، ويمكن تلخيص أهدافه

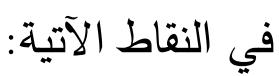

1- الوقوف على منهج الإمام الثاطبي في استخدام هذه المصطلحات.

r- توضيح معاني تلك المصطلحات، وبيان مراد الناظم من دلالتها.

r- استخلاص النتائج والفوائد من هذه الدراسة؛ للإفادة منها.

أهمية البحث: - n

تتلخص أهمية البحث في النقاط الآتية:

1- يعتبر البحث مفتاحاً للوصول إلى مراد الناظم من تلك المصطلحات. 
r- يسهح البحث في توضيح معاني أبيات الثاطبية.

r- معرفة منهج الإمام الثاطبي في استعمال تلك المصطلحات يسهم في

إزالة اللبس عن دارس المنظومة.

أسباب اختيار البحث:

وتتخلص في النقاط الآتية:

1- أهمية منظومة الثاطبية باعتبارها أهم الكتب التي يعتمد عليها طلاب

القراءات في دراسة القراءات السبع.

r- فهم مصطلحات القراء وبيان المراد منها له أثر كبير في الوقوف على

$$
\begin{aligned}
& \text { معنى النظم وبيان دلالته. } \\
& \text { منهج البحث: } \\
& \text { أولاً: المنهج العلمي: }
\end{aligned}
$$

يقوم هذا البحث على المنهج الاستقرائي، والمنهج الوصفي التحليلي، بتتبع اصطلاحات القراء في منظومـة الإمام الشاطبي، ودراستها بغية الوصول إلى الى

النتائج والفوائد من هذه الدراسة.

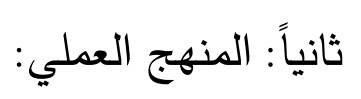

اشتمل البحث على مقدمة وتمهيد وسبعة مباحث وخاتمة تفاصيلها كما يلي: -المقدمة: واشتملت على أهمية الموضوع، وأهدافه، ومنهجه، والدراسات السابقة.

المبحث الأول: وجاء بعنوان: منهج الإمـام الثـاطبي في استعمال التسهيل والتحقيق. 
المبحـث الثاني: وعنوانـه: مـنهج الإمـام الثـاطبي في اسـتعمال التغلـيظ

$$
\text { والترقيق. }
$$

المبحث الثالث: وكـان بعنوان: منهج الإمـام الثـاطبي في استعمال المـ

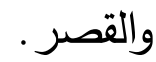

المبحـث الرابـع: وعنوانـه: مـنهج الإمـام الثـاطبي في استعمال الإظهـار

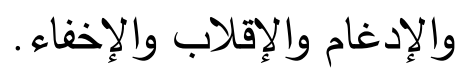

المبحث الخامس: وجاء بعنوان: منهج الإمـام الثاطبي في استعمال الفتح

$$
\text { والإمالة والتقليل. }
$$

$$
\text { والإشمام والاختلاس. البــادس: وعنوانـه: مـنهج الإمـام الثـاطبي فـي اسـعمال الـروم }
$$

المبحث السـابع: وهو بعنوان: منهج الإمـام الشـاطبي في استعمال الوقف

$$
\text { والسكت. }
$$

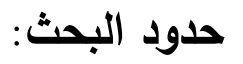

مصطلحات القراء التي استعملها الإمام الثـاطبي في منظومته الموسومة

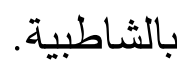




\section{المبحث الأول}

منهج الإمام الثاطبي في استعمال التسهيل والتحقيق

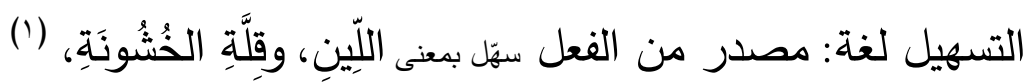
وفي اصطلاح القراء: هو النطق بالهمزة بحالة متوسطة بين الهمزة المحققة، وبين حرف المد المجانس لحركتها، وقد يطلق التسهيل ويراد بـه مطلق التغيير في الهمزة) (r). وقد اصطلح القراء على إطلاق لفظ التسهيل على التسهيل بين بين أي أن

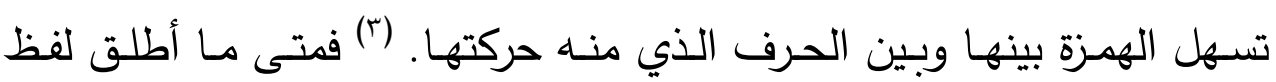
التسهيل عند فالمراد باه تسهيل الههزة بين بين.

جاء في كتاب مختصر العبارات لمعجم مصطلحات القراءات: (التسـهيل: جعل الهمزة بينها وبين الحرف المجانس لحركتها، فتجعل الهمزة المفتوحة بين الهمزة المحققة والألف، وتجعل المكسورة بين الهمزة المحققة والياء الممدودة،

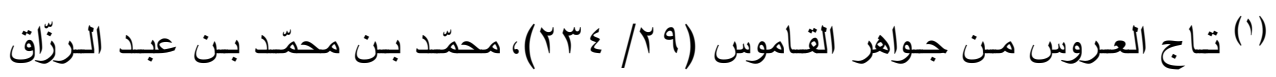

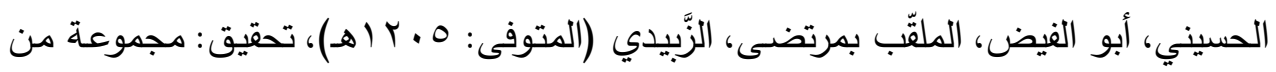
المحقين، الناشر : دار الهداية.

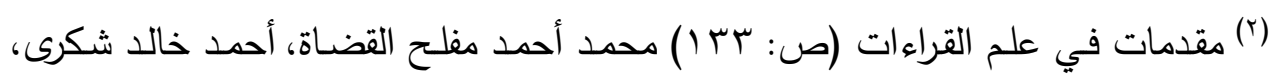

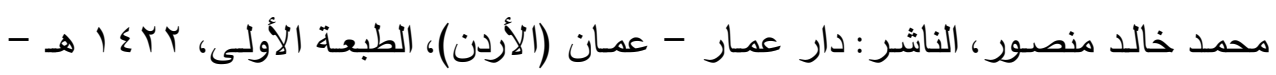

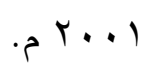

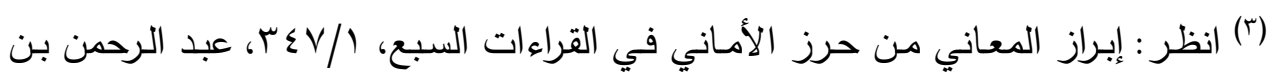
إبراهيم بن إسماعيل المعروف بأبي شامة المتوفى سنة ستمائة وخمس وستين هجرية. 
وتجعل المضـومة بين الهمزة والواو الممدودة، ولا يُضبط ذلك إلا بالمشـافهة

وهو أشهر معاني التسهيل وأكثرها استعمالاً). (')

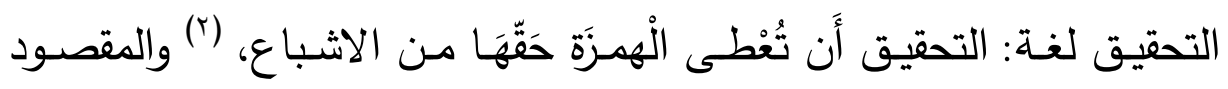

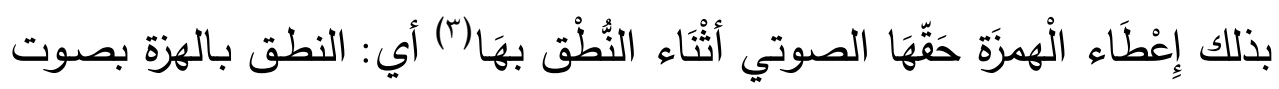
ظاهر واضح.

والتحقيق في اصطلاح القراء: النطق بالهمزة على صورتها كاملة الصفات

من مخرجها الذي هو أقصى الحلق(ء).

استعمل الناظم مصطلح التسهيل، وأرد بـه تسهيل الههزة بين بين كما في

قوله:

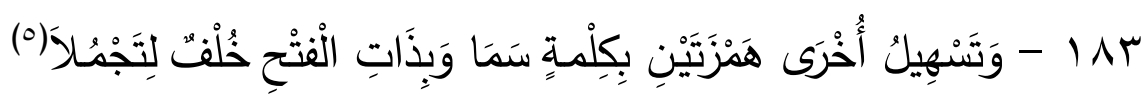

(') مختصر العبارات لمعجم مصطلحات القراءات (ص: V §)، إبراهيم بن سعيد بن حمد

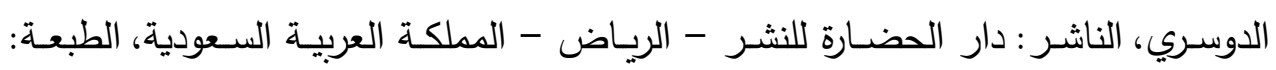

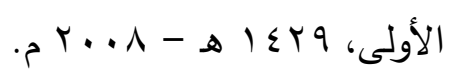

(ז) لسان العرب، (1/9 ( ) )، محمد بن مكرم بن على، أبو الفضل، جمال الدين ابن منظور

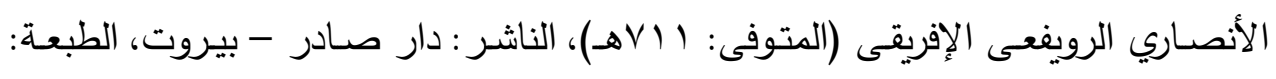

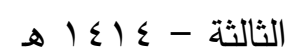

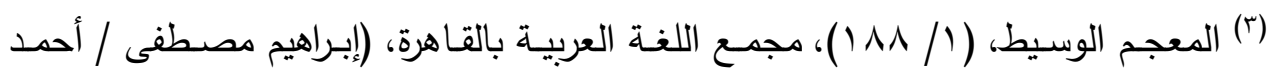

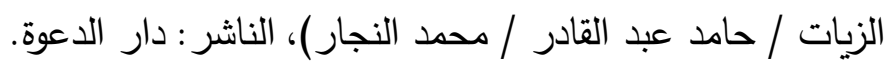

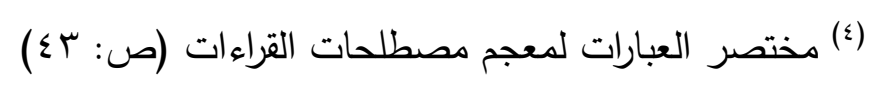

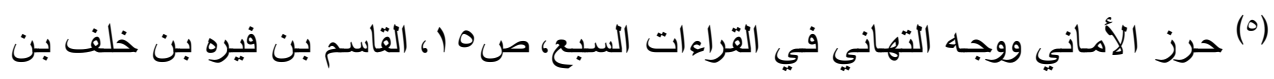
أحمد الرعيني الشاطبي الأندلسي المتوفى سنة خمسمة وتسعين هجرية، ضبط وتصحيح: 
فـالمراد بالتسـهيل هنـا: تسـهيل الهمـزة بينهـا وبـين الحرف الذي مـن جنس

حركتها كما بين ذلك شراح الشاطبية(').

وقد جاء عن الإمام الشـاطبي في منظومته في توضيح معنى التسـيل ما يدل على أنّه يريد من إطلاقة لفظ التسهيل تسهيل الههزة بين بين، كما في

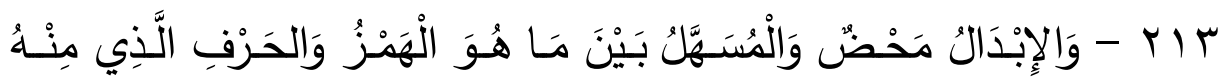

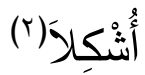

فقد بيّن في هذا البيت حقيقة الإبدال، وأنّه ابدال الهمزة حرف مد خالص لم يبق فيه شـائبة لفظ الههزة، وبيّن التسهيل بأنّه: النطق بالههزة بينها وبين مـا حركت بـهـ(َ)، وهـذا يـدل دلالــة واضـحة على أنّ الإمـام الثـاطبي يسـتخدم مصطلح التسهيل في منظومته للدلالة على تسهيل الهمزة بين بين.

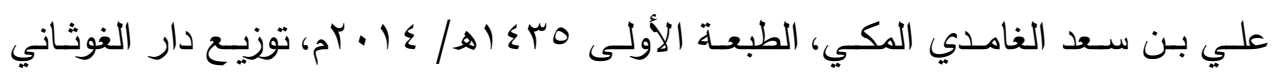

$$
\text { للدراسات القرآنية - دمشق - سورية. }
$$

(') سراج القارئ المبتدئ وتذكار المقرئ المنتهي، ص باته، أبو القاسم علي بن عثمان بن

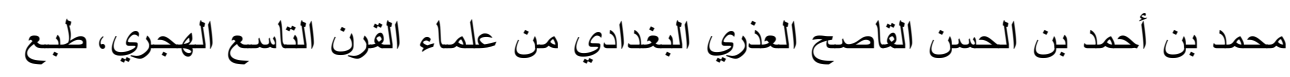

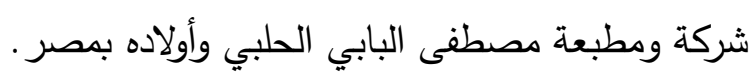

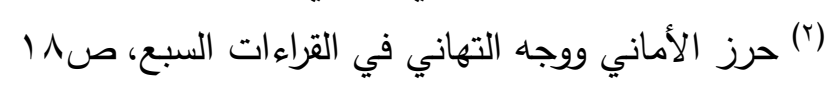

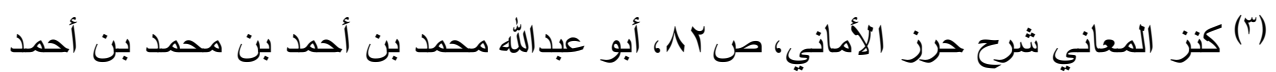
بن الحسين الموصلي المعروف بشعلة المتوفى سنة ستمائة وست وخمسين هجرية، تحقيق:

$$
\text { الثيخ زكريا عميرات، الطبعة الثانية، دار الكتب العلمية - بيروت لبنان. }
$$


وعبر عن أنواع التغيير الأخرى في الهمـز بمسـياتها، كما في قولـه في

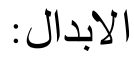

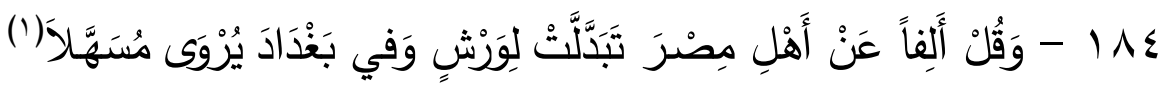
وقوله في حذف الهمزة أو إسقاطها:

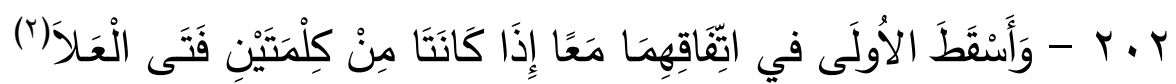
وقال أيضاً:

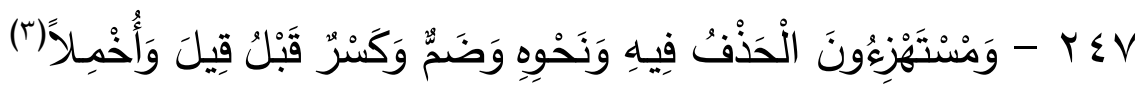
وقوله في النقل: - 20 - 20

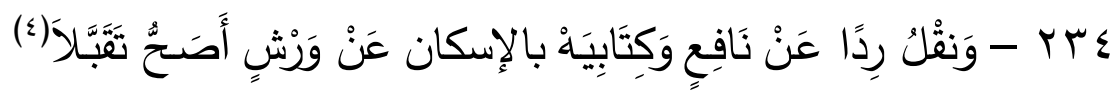
وبتتبع استعماله لكلمـة التسـهيل، وجد الباحث أنّ الإمـام الثـاطبي استعمل التسهيل في بعض المواضع، وأراد به نوعين من أنواع تغيير الهمز هما: الأول: الابدال والتسهيل بين بين، والثاني: مطلق التغيير في الهمز. أما استعماله لكلمة التسهيل بمعنى الابدال وبمعنى التسهيل بين بين، فقد جاء ذلك في قوله:

(') حرز الأماني ووجه التهاني في القراءات السبع، ص10

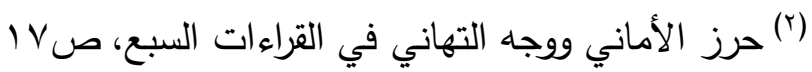

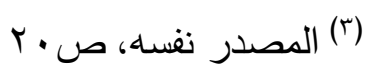

$$
\begin{aligned}
& \text { () المصدر نفسه، ص19 }
\end{aligned}
$$




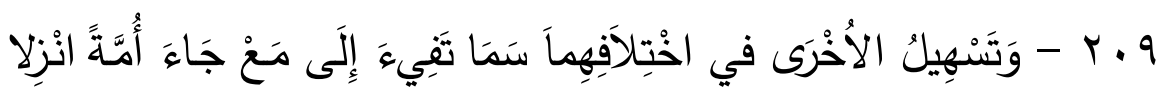

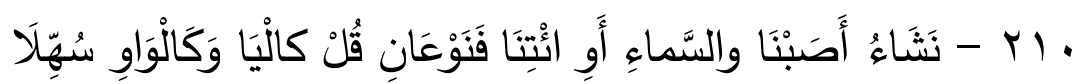

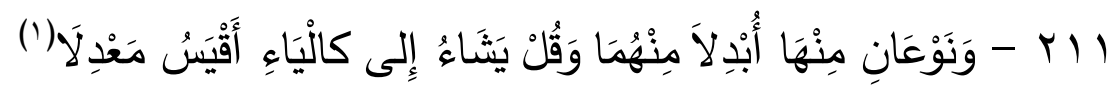

ومما يدل على ذلك أنّه أطلق لفظ التسهيل في الهمزة الثانية لأهل سما، وهم: نافع وابن كثير وأبي عمرو، ثم فُصل هذا التسهيل بأنّ المراد به التسهيل بين بين في النوع الأول والثاني من الهمزتين المختلفتين في الحركات، وهما: المكسورة بعد فتح، والمضدومة بعد فتح، وأنّ المراد بالتسـهيل الذي أطلقه في بداية كلامه الابدال، وذلك في النوع الثالث والرابع من الهمزتين المختلفتين في الحركات وهما: المفتوحة بعد ضم والمفتوحة بعد كسر ، وأنّ النوع الخامس من أنواع الهمزتين المختلفتين في الحركات، وهي المكسورة بعد ضم، فقد وضتح أنّ المـراد بالتسـهيل فيها: الابـدال، والتسـهيل بين بين حسب مذاهب القراء فيها، فأجمل لفظ التسهيل في أول كلامه، ثم بيّن أنّ المراد بـه: التسهيل بين بين،

$$
\text { والابدال كما سبق إيضاحه. }
$$

وأما استعماله لكلمة التسهيل بمعنى مطلق التغيير في الههز ، فقد جاء ذلك

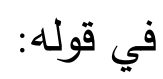

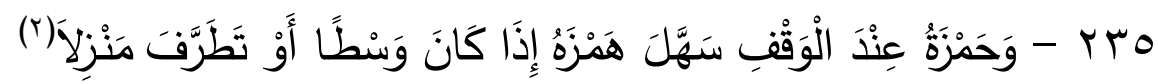
وتسهيل الههز عند الوقف كما هو معلوم من مذهب حمزة، هو تغيير الههز

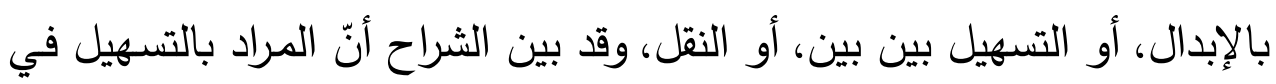

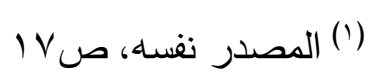

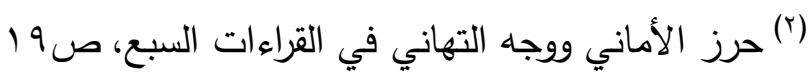


كلام الشاطبي هنا هو مطلق التغيير، فشمل أنواعه الأربعة: بين بين، والنقل،

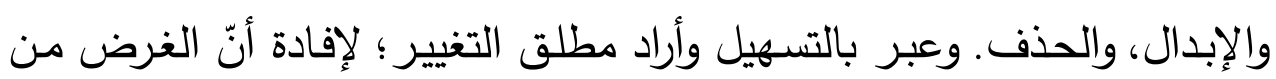

التغيير تسهيل النطق باللفظ الذي فيه الهمز. (') والابدال، والنيل

وأمسا التحقيق فقد جاء في كلام الناظم - رحمهـ الله - للدلالة على معنى التحقيق الذي سبق بيانه، وقد جاء ذلك في مثل قوله:

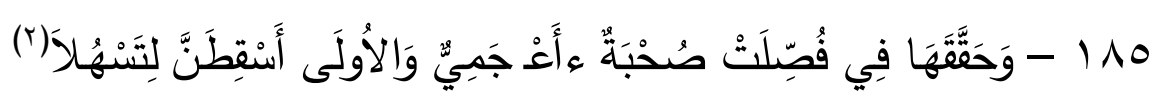
فالمراد بالتحقيق في كلامه عكس لفظ التسهيل أي النطق بالهمزة محققة غير لينة قـال الإمـام أبـو شـامة: (وفي معنى النقل لفظـا التسـهيل والإبـدال كقولـه:

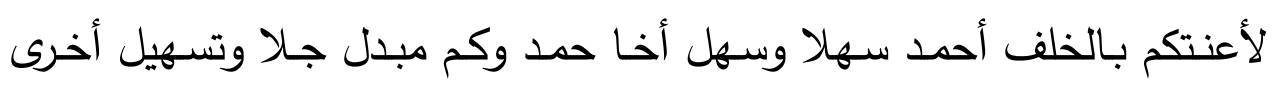

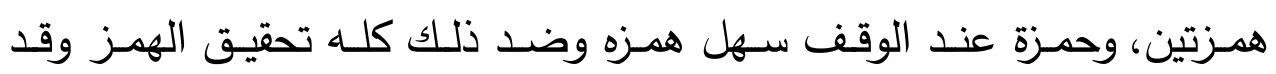

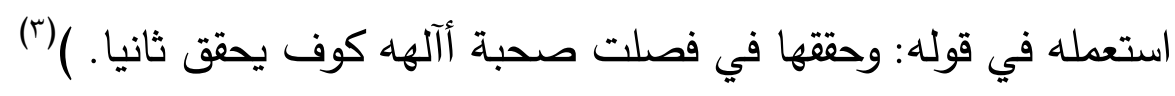
والخلاصة أن الناظم استعمل مصطلح التسهيل وأراد به تسهيل الههزة بين بين، واستعمل هذا المصطلح للدلالة على أنواع التغيير في الهمز كما مر في لفي

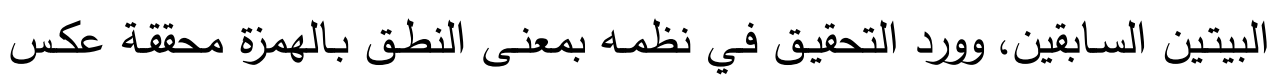
التسهيل

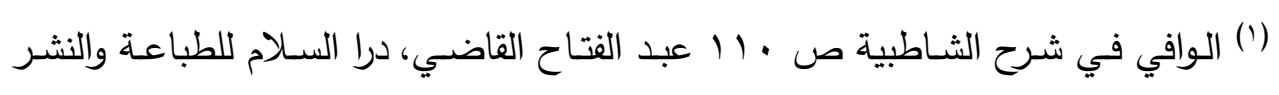

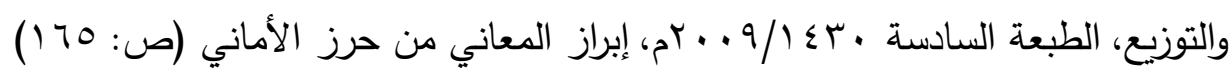

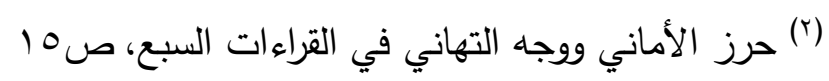

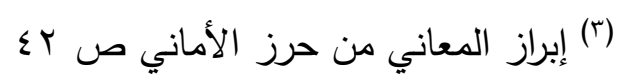




\section{المبحث الثاني}

\section{منهج الإمام الشاطبي في استعمال التغليظ والترقيق}

التغليظ: مصدر علّظ بمعنى شدد، (') وهو خـلاف الرقة، والاسم منـه: غليظ، وهو الشديد القوى(ז)، فتغليظ الصوت المراد به الثدة التي هي عكس الترقيق في الحرف.

والتغليظ في اصطلاح القراءة: هو سمن يعتري الحرف المراد تغليظه، فيملأ

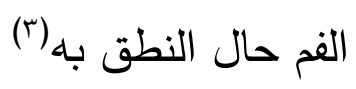

والتغليظ مرادف للفظ التفخيم عند القراء، لكن التغليظ أكثر ما يستعمل في اللامات، والتفخيم أكثر ما يستعمل في الراءات(؛)، ويطلق أهل اللغة لفظ التفخيم

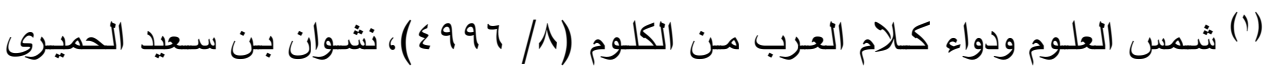
اليمني (المتوفى: سOVAه)، تحقيق: د حسين بن عبد الله العمري - مطهر بن علي الإرياني

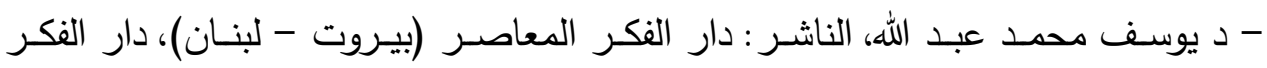

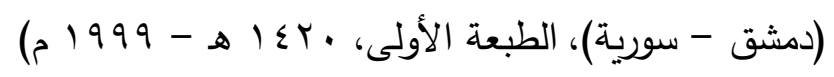

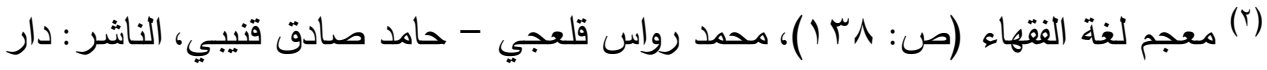

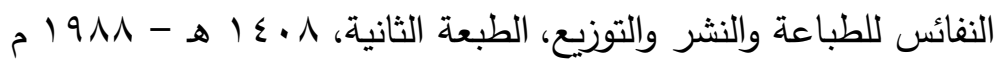
(َ) القواعد والإشـارات في أصسول القراءات (ص: •.0) أحمد بن عمر بن محمد بن أبي الرضنا، الحموي الحلبي (المتوفى: (الولهـ)، تحقيق: الدكتور عبد الكريم بن محمد الحسن

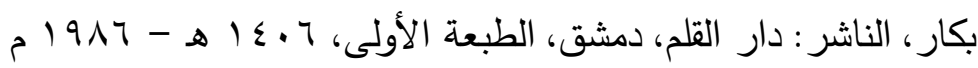

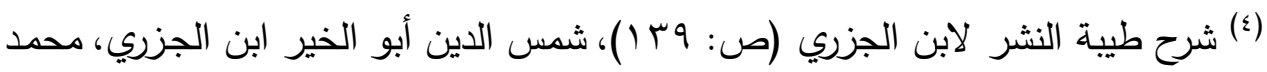

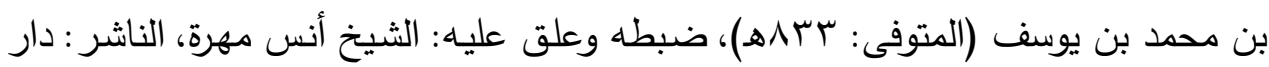

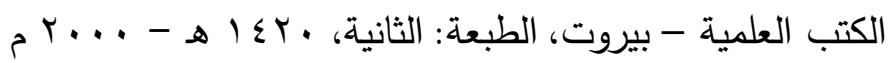


بمعنى الفتح الذي هو ضد الإمالة، (') ويستعلمه القراء بمنعى ترك الإمالة تجـوزاً، (r) إلا أنّ أكثر مـا يستعمل التغليظ في تغليظ اللامـات، والتقخيم في تفخيم الراءات، وقد مشى الناظلم على هذا الاصطلاح في التفريق بين لفظ التفخيم والترقيق كما في قوله:

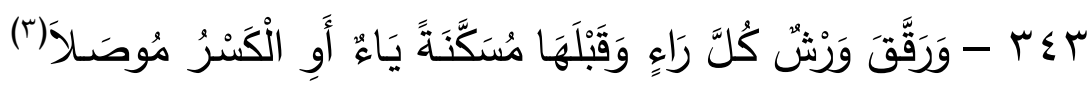

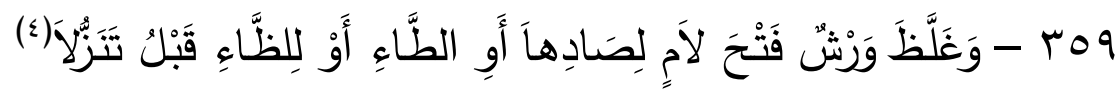
والترقيق لغـة: مصـدر للفعل رقق، والترقيق ضـد الغليظ والثخين، (0) وهو

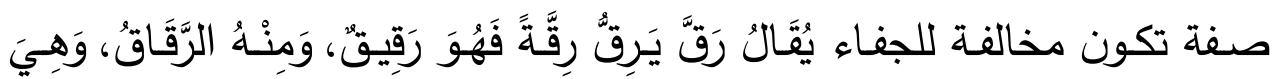

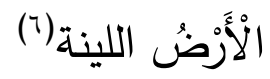

(') الكليـات معجـم فـي المصـطلحات والفـروق اللغويـة (ص: 1 • بـ)، أيـوب بـن موسـى

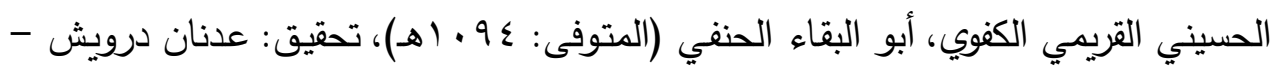

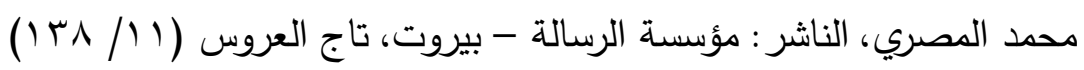

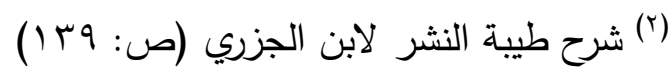

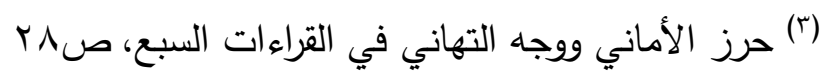

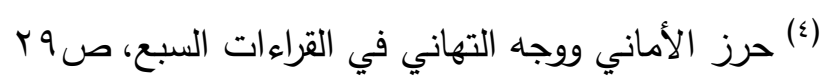

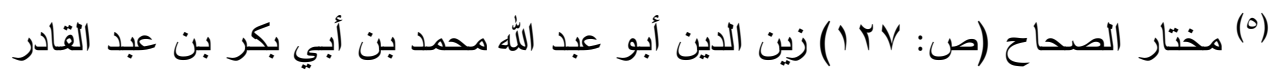

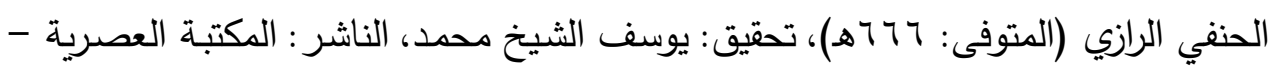

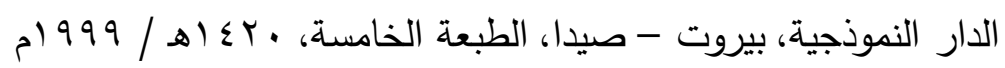

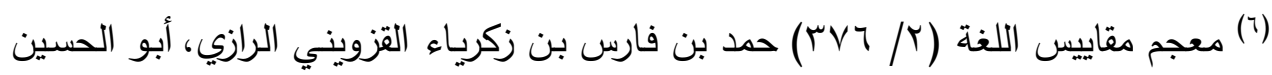

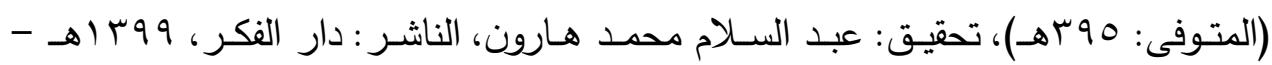


والترقيق في اصطلاح القراء: نحول يعتري الحرف فلا يملأ صداه الفر. (')

وهو عند أهل اللغة بمعنى الإمالة التي هي ضد الفتح وكذا استعمله القراء بمعنى الإمالة لكن بقلة.

وقد استخدم الناظم لفظ الترقيق بمعنى الإمالة، ولفظ التفخيم بمعنى الفتح الذي هو ضد الإمالة، كما في قوله:

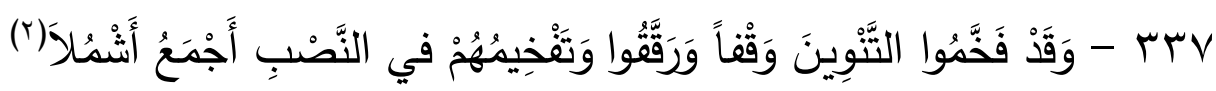
قال الإمـام أبو شـامة: (رقق: أي أمسال بين بين قال في التيسير : اعلم أن ورشا كان يميل فتحة الراء قليلا بين اللفظين، وكذا قال في باب الإمالة وقال مكي: كان وش يرقق الراء، فيعلم من هذا الإطلاق أن الترقيق في هذا الباب عبارة عن إمالة بين بين ويستخرج من هذا أن إمالة الألفات بين بين على لفظ الترقيق في هذا الباب على ما ينطق به قراء هذا الزمان). (r) فالإمام أبو شامة يرى أن الترقيق والإمالة في الراء معناهما واحد، لا فرق بين تسميته ترقيقا، أو إمالة، وذلك لأنّ ما يعمل بالراء من الترقيق، إنما هو إمالة لها بين بين.

وقد رد الإمـام ابن الجزري على من يرى أنّ الترقيق إنما هو الإمالة بين بين، وأنّه لا فرق بينهما بقوله: (ولو كان الترقيق إمالة لم يدخل على المضدوم

$$
\begin{aligned}
& \text { (') مقدمات في علم القراءات (ص: هب (1) }
\end{aligned}
$$

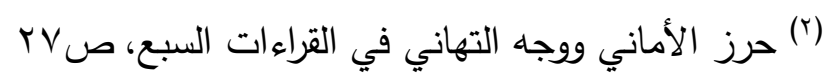

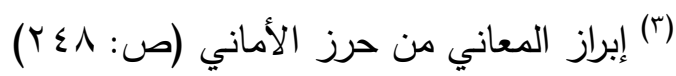


والساكن ولكانت الراء المكسورة ممالة، وذلك خلاف إجماعهم، ومن الدليل أيضاً على أنّ الإمالة غير الترقيق أنك إذا أملت ذكرى التي هي فعلى بين بين كان لفظك بها غير لفظك بذكر المذكر وقفاً إذا رققت، ولو كانت الراء في المذكر بين اللفظين لكان اللفظ بهما سواء وليس كذلك، ولا يقال : إنّما كان اللفظ في المؤنث غير اللفظ في المذكر لأن اللفظ بالمؤنث ممال الألف والراء واللفظ بالمذكر ممال الراء فقط فإنّ الألف حرف هوائي لا يوصف بإمالة، ولا تفخيم، بل هو تبع لما قبله فلو ثبت إمالة ما قبله بين اللفظين لكان ممالاً بالتبعية كما يأل أملنا الراء قبله في المؤنث بالتبعية، ولما اختلف اللفظ بهما والحالة ما ذكر، ولا

$$
\text { مزيد على هذا في الوضوح )(') }
$$

ويؤيد كلام الشيخ رحمه الله - أن الإمالة هي: أن تتحو بالألف نحو الياء وبالفتحة نحو الكسرة، والإمالة بين بين، وهي الإمالة الصغرى مرتبة متوسطة بين الفتح والإمالة، فالقارئ ينحو بالألف نحو الياء، وبالفتحة نحو الكسرة من غير مبالغة في ذلك، وهذا ما لا يحدث في الترقيق فإن الترقيق تتحيف الحرف كما مضى دون الميل به، كما أنّ الترقيق يكون في أحرف معينة، بينما الإمالة تكون في الألف والكسرة، وعلى هذا فاستخدام الناظم لمصطلح التفخيم بمعنى الفتح، واستخدامه للترقيق بمعنى الإمالة إنّما هو من باب التجوز •

(') النشر في القراءات العشر (ץ/ • 9)، شمس الدين أبو الخير ابن الجزري، محمد بن

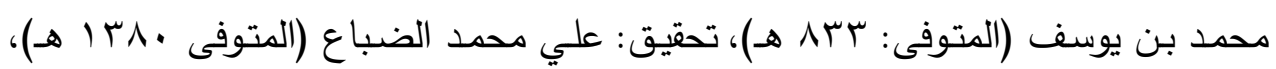
الناشر : المطبعة التجارية الكبرى [تصوير دار الكتاب العلمية]. 


\section{المبحث الثالث}

منهج الإمام الثاطبي في استعمال المد والقصر

المد لغة: المد مصدر للفعل مدد، ومعناه: الزيادة والطول (')

وفي اصطلاح القراء : إطالة زمن الصوت بحرف المد عند ملاقاته لهمز ، أو

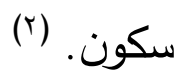

والقصـر لغـة : مـن الفعـل قصـر بمعنـى منـع وحَبَسَ، (َ) والقَصْـرُ : خـلافُ

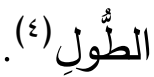

والقصر في اصطلاح القراء : إثبات حرف المد أو اللين من غير زيادة فيه؛

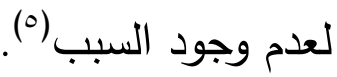

(') الصحاح تاج اللغة وصحاح العربية (T/Orv) أبو نصر إسماعيل بن حماد الجوهري

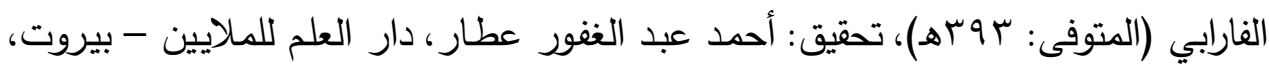

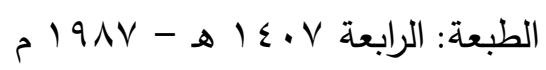

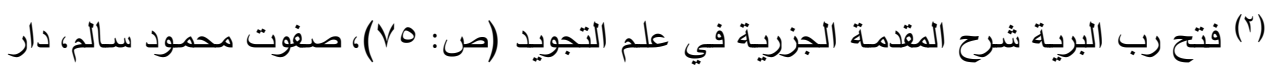

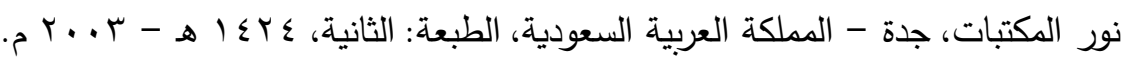

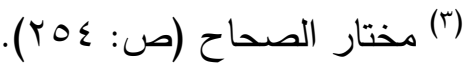

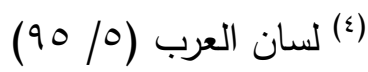

(o) غايـة المريد في علم التجويد (ص: بو9)، عطية قابل نصر، الناشـر : القاهرة، الطبعـة:

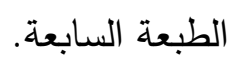


اسـتعمل النـاظم - رحمــه الله - مصـطلح المــ، وأراد بــه الزيـادة، وإطالــة

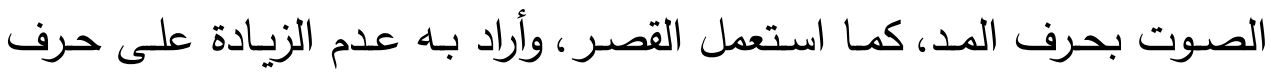

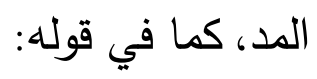

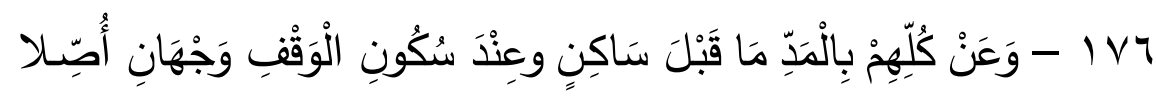

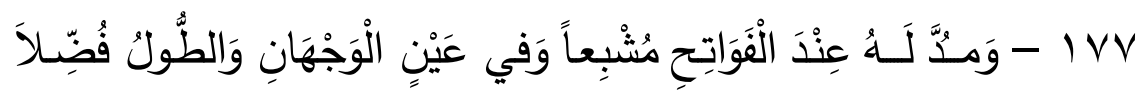

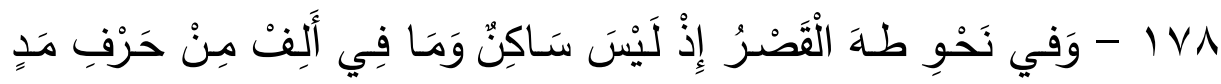
(') فَيُمْطَلَ فالمراد بالمد في كلامها الزيادة على حرف المد، والمراد بالقصر في كلامها ترك الزيادة في حرف المد، كما بين ذلك شراح الثاطبية(؟). غير أنّ الثشيخ - ر حمـه الله - ورد عنـه في كلامـه استعمال مصـطلح

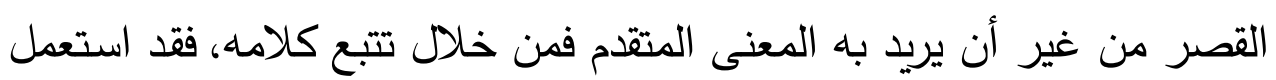

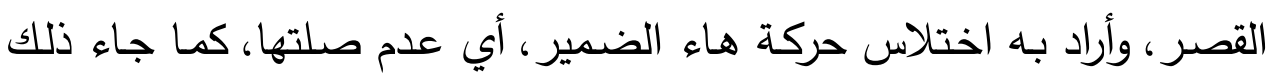

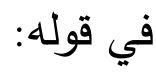

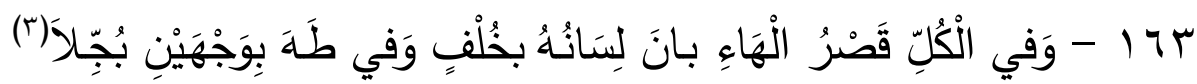

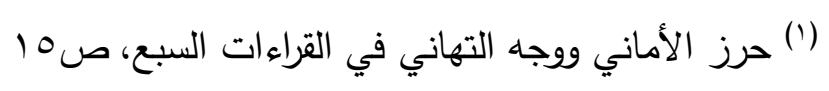

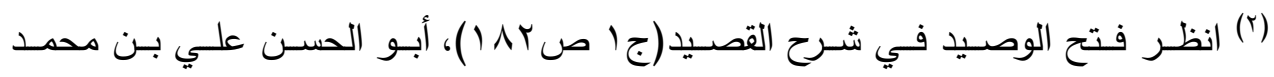

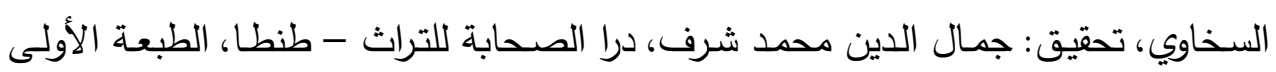

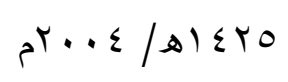

(r) حرز الأماني ووجه التهاني في القراءات السبع، صع إم 
جاء في شـروح الثـاطبية: أنّ المراد بالقصر في هنا اختلاس حركة الهاء وهو عدم صلتها (').

كما استعمل الناظم - رحمه الله- المد بمعنى اثبات الألف، واستعمل القصر بمعنى حذف الألف، وذلك كثير في نظمه، ومن أمثلته قوله:

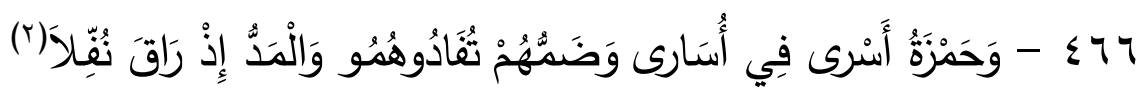
فالمد في كلمة (تفادوهم) اثبات الألف ويلزم من ذلك فتح الفاء(r) وقوله في القصر :

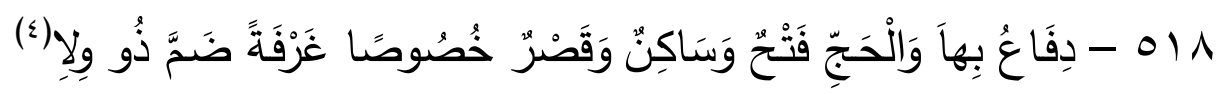
فالقصر في كلمة (دفاع) حذف الألف التي بعد الفاء. (•) ويتلخص مما سبق: أنّ الناظم استعمل مصطلح المد، واراد بـه زيـادة حرف المد، واستعمل مصطلح القصر، وأراد به اثبات حرف المد من غير زيادة، كما

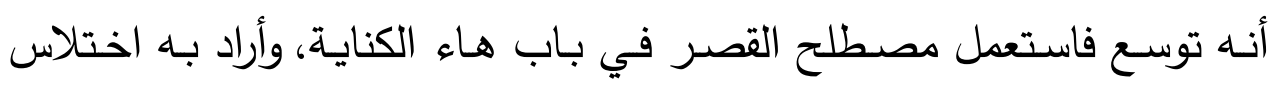
حركة الهاء، واستعمل مصطلح المد وأراد بـه اثبات الألف، ومصطلح القصر وأراد به حذف الألف وهذا كثير في منظومته.

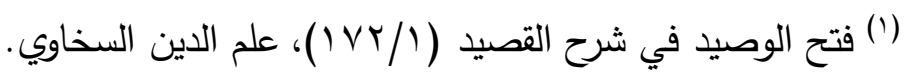

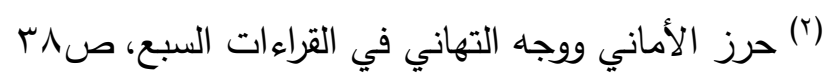
(־) إبراز المعاني من حرز الأماني (ص: عسب)

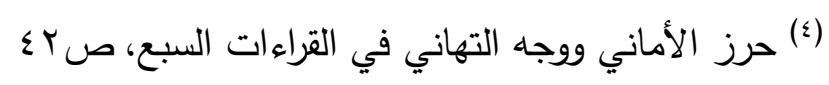

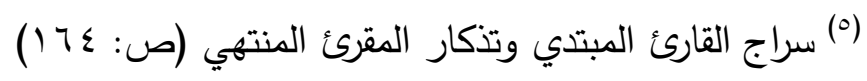




\section{المبحث الرابع}

منهج الإمام الثاطبي في استعمال الإظهار والإدغام والإقلاب والإخفاء

الإظهار لغة: البيان تقول أظهرت الثئ بمعنى بينته(').

وفي اصطلاح القراء: إخراج الحرف الُْْظْهره من مخرجه من غير غنة كاملة(r).

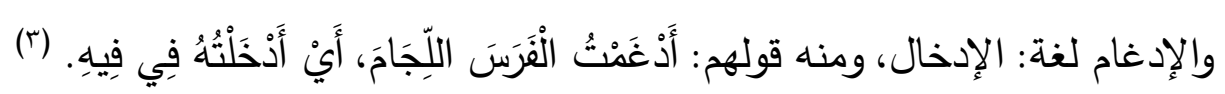

وفي اصطلاح القراء: عبارة عن خلط الحرفين، وتصييرها حرفاً واحداً مشدداً. (๕)

الإقلاب لغة: من القلب. وهو تَحْويلُ الثيِيٍ عَنْ وَجْهِه. (ن)

وفي اصطلاح القراء: عبارة عن قلب النون السـاكنة، أو التتوين ميمًا، ثم

إخفاؤها بغنَّة عند الباء فقط آ).

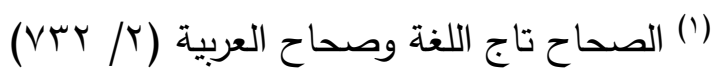

$$
\begin{aligned}
& \text { (r) غاية المريد في علم التجويد (ص: عـ) } \\
& \text { (") مختار الصحاح (ص: } 0 \text { (1) }
\end{aligned}
$$

(؛) التمهيد في علم التجويد (ص: 00)، شمس الدين أبو الخير ابن الجزري، محمد بن محمد بن يوسف (المتوفى: بr/هـ)، تحقيق: الدكتور على حسين البواب، الناشر : مكتبـة

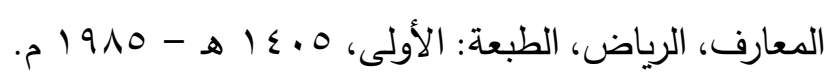

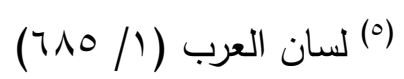

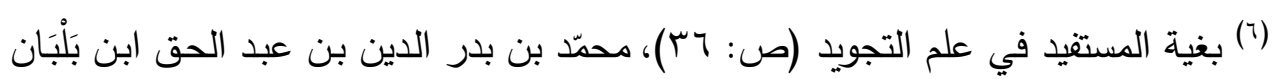
الحنبلي (المتوفى: rی • ا هـ)، اعتىى بـه: رمزي سعد الدين دمشقية، الناشر : دار البشائر 
والإخفاء لغة: من أخفى بمعنى الستر ، والتغطية،، وأخفيته إذا سترته('). وفي اصطلاح القراء: إخفاء الحرف الأول عند الحرف الثاني مع بقاء صفة الغنة، وهو حالة بين الإظهار والإدغام(؟).

وردت هذه المصطلحات في كـلام الناظم - رحمـه الله -، واستعملها بنفس المدلول الذي اصطلح عليها القراء، حيث جاء ذلك في قوله:

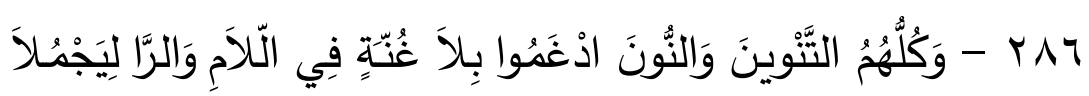

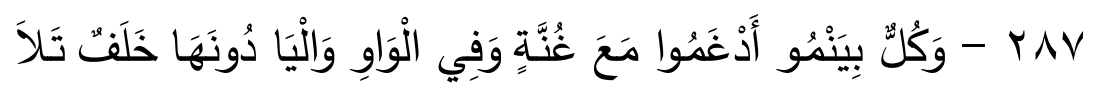

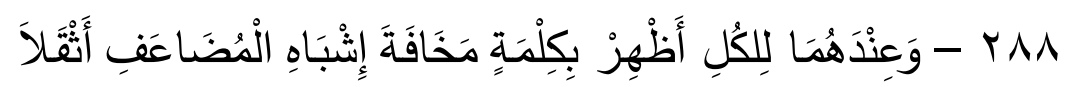

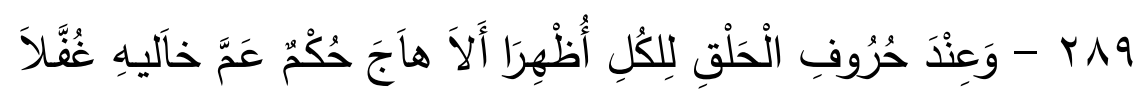

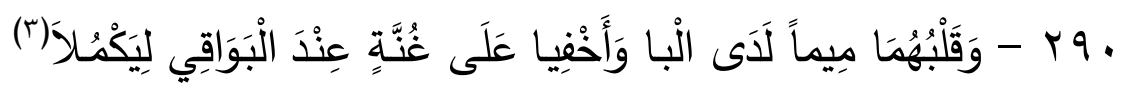
تحدث -رحمه الله - عن أحكام النون الساكنة والتنوين، فبيّن أنّها الإظهار، والإدغام، والإقـلاب، والإخفاء، وأنّ لكل منها حروفه الخاصـة بـه، فحكم النون

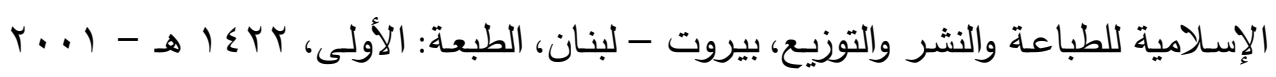

(') جمهرة اللغة (1/ / / آ) أبو بكر محمد بن الحسن بن دريد الأزدي (المتوفى: ابسهـ)،

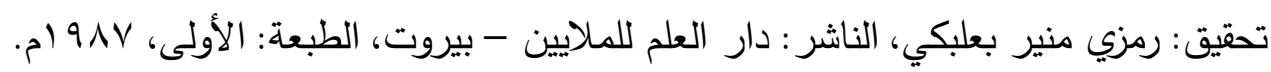

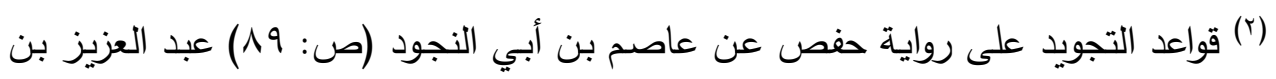
عبد الفتاح القارئ، الناشر : مؤسسة الرسالة.

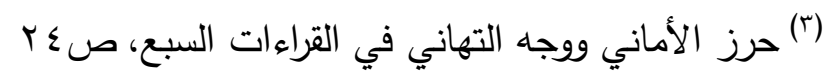


الساكنة والتنوين الإظهار عند حروف الحلق السنة الههزة والهاء والعين والحاء

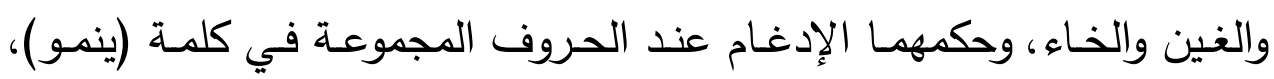
ويكون حكمهـا الإقـاب أو القلب عند حرف البـاء، وأخبر أن النون السـاكنة والتتوين تخفى عند باقي حروف الهجاء (').

وقد استعمل مصطلح الإخفاء وأراد بـه الاختلاس، كما جاء ذلك في عدة مواضع منها قوله:

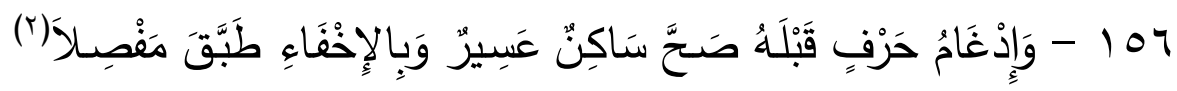
وقوله:

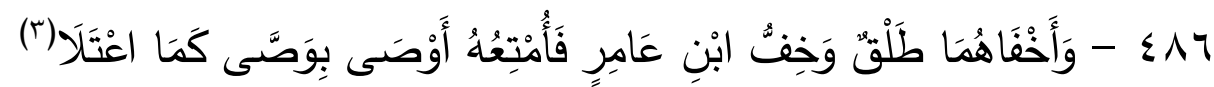
وقوله:

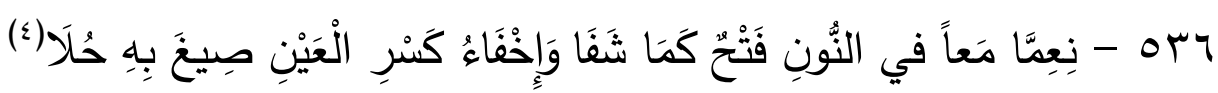
فقد جاء في شـروح الثـاطبية أن المراد بالإخفاء هنا اختلاس الحركة فإن الاختلاس يطلق عليه اخفاء(0) لأن القارئ يخفي بعض الحركة وينطق بالأكثر منها.

$$
\text { (') الوافي في شرح الثاطبية (ص: مب ا). }
$$

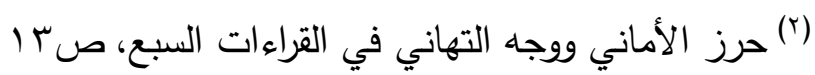

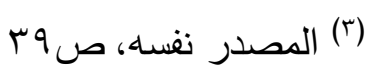

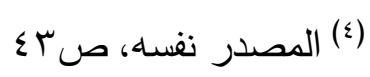

$$
\begin{aligned}
& \text { (•) إبراز المعاني من حرز الأماني (ص: 1. (1) }
\end{aligned}
$$


كما استعمل الناظم استعمال مصطلح الإخفاء بمعنى الاسـرار ، وذلك في باب الاستعاذة حيث قال:

99

فمقصود الناظم بالإخفاء هنا هو إخفاء التعوذ، أي الإسرار به. (r)

واطلاق مصطلح الإخفاء بمعنى الإسرار، إنّما هو على الاستعمال اللغوي

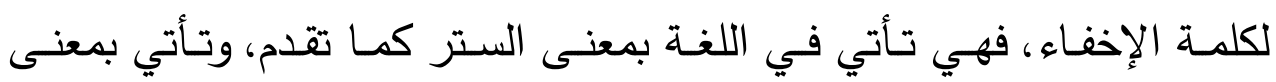

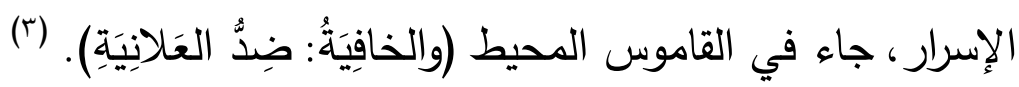

ويتضـح مما سبق أن الناظلم - رحمـه استعمل الإظهار والإدغام والإقلاب والإخفاء وفق ما اصطلح عليه القراء، وأرادوه من إطلاقهم لهذه المصطلحات، كما أنّه استعمل الإخفاء بمعنى الاختلاس، وتصـرف في الإخفاء فاستعمله بمعنى الإسرار، وذلك وفق المعنى اللغوي لكلمة الإخفاء.

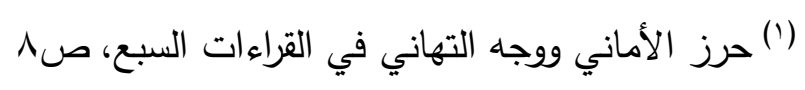

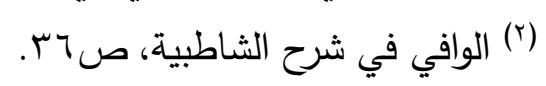

(r) القاموس المحيط (ص: • Y Y )، مجد الدين أبو طاهر محمد بن يعقوب الفيروزآبادى (المتوفى: N V Vهـ)، تحقيق: مكتب تحقيق التراث في مؤسسة الرسالة بإثراف: محمد نعيم

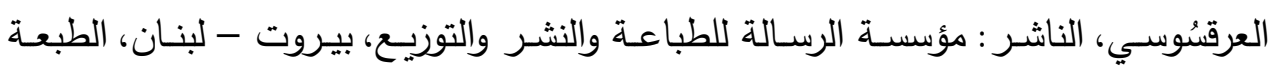

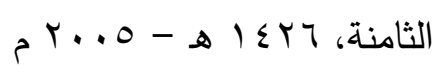




\section{المبحث الخامس}

\section{منهج الإمام الثاطبي في استعمال الفتح والإمالة والتقليل}

$$
\text { الفتح لغة: من فتح ضد أغلق. (') }
$$

والفتح في اصطلاح القراء : فَتْحُ الْقَارِيُ فَهـه بِلَفْظِ الْحَرْفِ.

الإمالة لغة: مالَ إليه مَيْلاً بمعنى عدل. (r)

والإمالة في اصطلاح القراء: والإمالة أن تقرب الفتحة من الكسرة، والألف

من الياء، من غير قلب خالص، ولا إشباع مبالغ (؛).

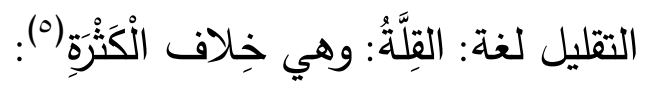

والتقليل في اصطلاح القراء: النطق بالحرف بين الفتح وبين الإمالة. (؟)

(') تاج العروس من جواهر القاموس (V/ ه)، حمّد بن محمّد بن عبد الرزّاق الحسيني، أبو

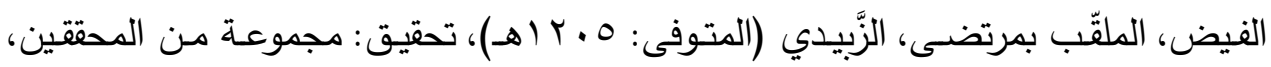
الناشر : دار الهداية

(r) الإتقان في علوم القرآن (1/ / / (ب)، عبد الرحمن بن أبي بكر، جـلال الدين السيوطي

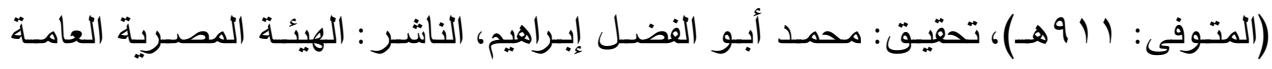

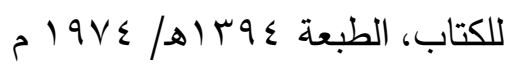

(r) القاموس المحيط (ص: ()

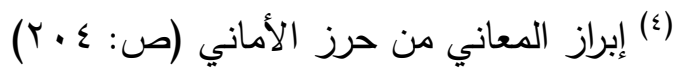

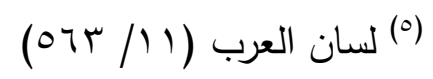

(־) إبراز المعاني من حرز الأماني (ص: ؟ •؟ب) 
ورد لفظ الفتح والإمالـة والتقليـل في كـلام النـاظم في عـدة مواضـع. كمـا اصطلح عليها القراء، ومن ذلك قوله:

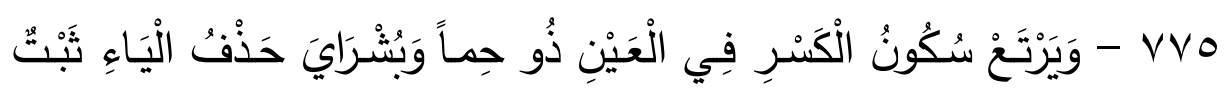
وَمْيَّلَ

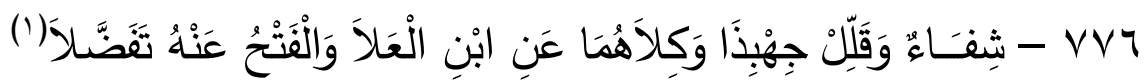
وفي بعض المواضـع أطلق على الإمالة لفظ الإضـجاع، وهو عند القراء مرادف للإمالة الكبرى، (r) ومن ذلك قوله:

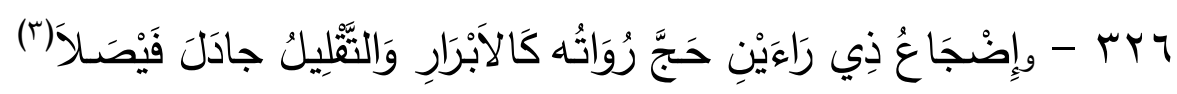
فالمقصـود بالإضــاع هنـا الإمالـة الكبـرى(ع) خاصــة وانّهـه ذكره في مقابـل التقليل.

وقد تقدم أنّ الناظم اطلق التفخيم، وأراد بـه الفتح، وأطلق الترقيق وأراد بـه الإمالة عند الكلام على منهجه في التغليظ والترقيق.

(') حرز الأماني ووجه التهاني في القراءات السبع (ص: (7).

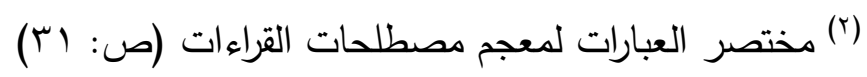

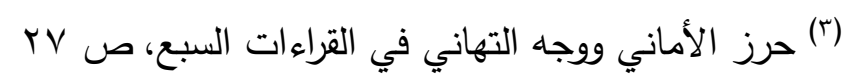

(؛) سراج القارئ المبتدي وتذكار المقرئ المنتهي (ص: 
ومما تقدم يلحظ الباحث أن الناظم - رحمـه الله - استعمل مصطلح الفتح

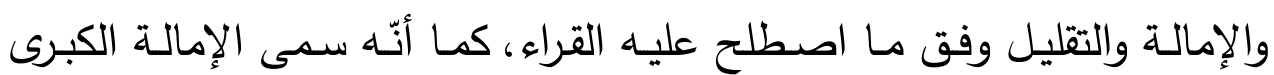

اضجاعاً، وأطلق لفظ التفخيم على الفتح، ولفظ الترقيق على الإمالة. 


\section{المبحث السادس}

\section{منهج الإمام الشاطبي في استعمال الروم والإثمام والاختلاس}

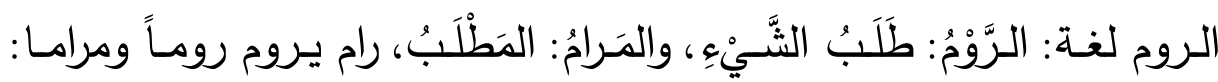

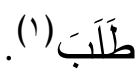

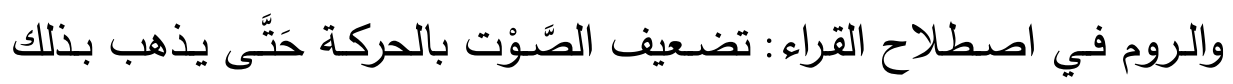

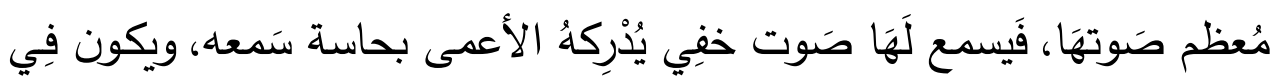

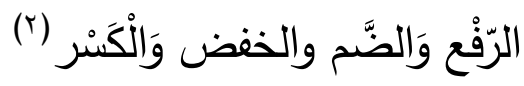

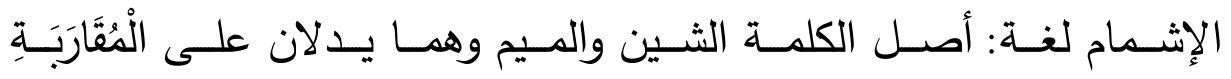

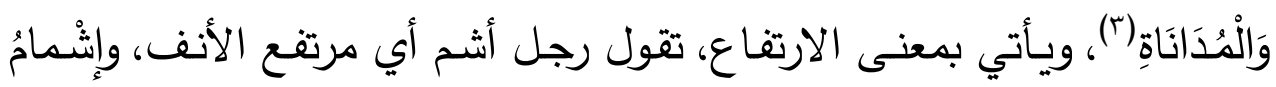

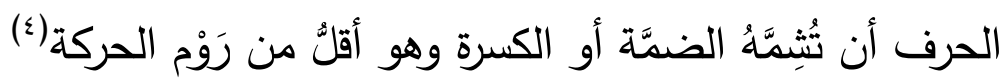

والإثـمام في اصطلاح القراء : ضم الثفتين بعد سُكُون الْحَرْف، وَلَا يذرك

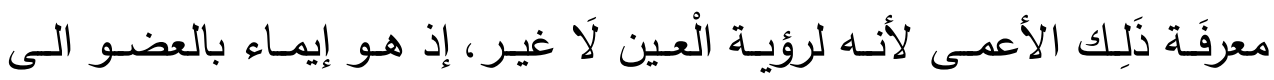

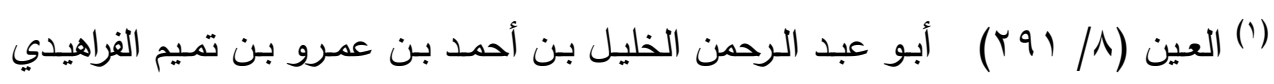

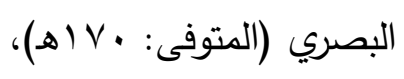

تحقيق: د مهدي المخزومي، د إبراهيخ السامرائي، الناشر : دار ومكتبة الهلال.

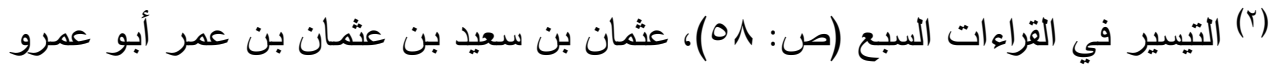

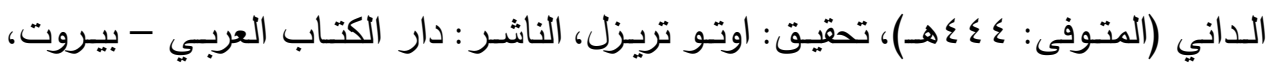

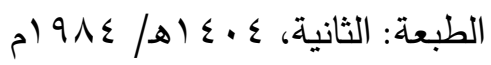

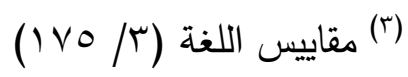

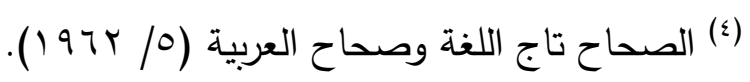


الْحَرَكَة، وَيكون فِي الرَّفْع وَالضَّم فقط (') ويأتي بمعنى خلط حركة بحركة، نحو: \}قيل\{ في قراءة من أشم، (r) وقد يطلق ويراد بـه خلط حرف بحرف في نحو:

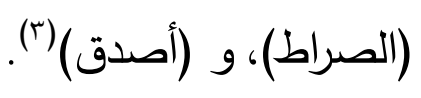

الاختتلاس لغة: من خَلَسَ، وَهُوَ الإخْتِطَافُ وَالِالْتِمَاعُ. (ع)

والاختلاس في اصطلاح القراء: وهو إسراع بالحركة ليحكم السامع بذهابها، وهي كاملة الوزن، والصفة، وهو مرادف للاختطاف (*)، ويقدر الاختلاس بذهاب ثلث الحركة وبقاء ثلثيها (؟).

فهنالك فرق عند القراء بين الروم والإشمام؛ فكلٌ منهما يتفق في ذهاب بعض الحركة، لكن يذهب أكثر الحركة في الروم، ويبقى الأقل، والعكس في الاختلاس يذهب الأقل، ويبقى الأكثر، كما أنّ الروم يكون في الوقف، والاختلاس يكون في الوصل، والاختلاس يدخل على كل الحركات، بينما يكون الروم في الكسر والضم.

قال ابن الجزري - رحمـه الله - (فالروم عند القراء غير الاختلاس، وغير الإخفاء أيضا. والاختلاس والإخفاء عندهم واحد ولذلك عبروا بكل منهما عن

$$
\text { (') التيسير في القراءات السبع (ص: م^) }
$$

(r) مختصر العبارات لمعجم مصطلحات القراءات (ص: (ro: (r)

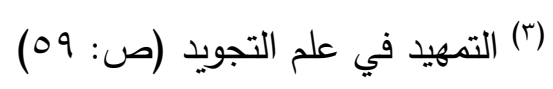

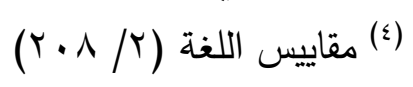

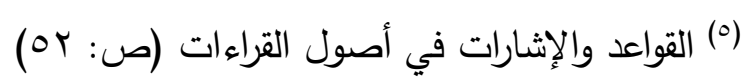

(1) مختصر العبارات لمعجم مصطلحات القراءات (ص: ؟ ؟ ). 
الآخر كما ذكروا في أرنا، ونعما، ويهدي، ويخصمون، وربما عبروا بالإخفاء عن الروم أيضا كما ذكر بعضهم في تأمنا توسعا. ووقع في كلام الداني في كتابه التجريد أن الإخفاء والروم واحد، وفيه نظر)(').

وقد استخدم الناظم - رحمـه الله - كل هذه المصطلحات وفق مـا اصطلح عليـه القراء، فأطلق الإشـمام، والـروم، والاختلاس، لكنّه كثيراً مـا كـان يسـي الاختلاس اخفاء، كما هو الاصطلاح عند القراء،وقد تقدم بيان ذلك عند الكلام على إخفاء النون الساكنة والتتوين. جاء الروم والإشمام بمعناهما المعروف في نحو قول الناظم:

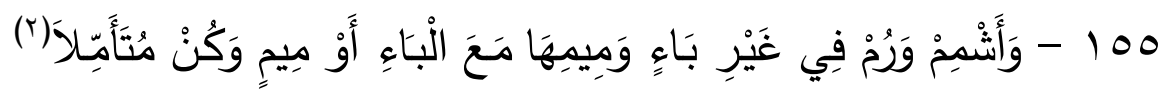
فالإشمام هنـا ضـم الشفتين، والروم النطق ببعض الحركة، وذلك في حال ادغـام حرف في حرف، فللقارئ إشـمام حركة الحرف الأول المدغم إن كـان

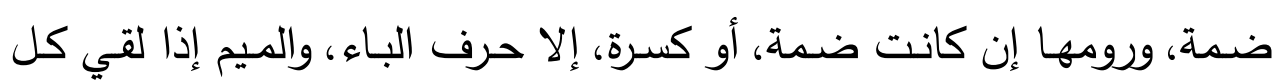
واحد منهما الباء والميم لانطباق الشفتين بالباء والميم(r). كما أنه - رحمه الله - وضح حقيقة الروم والإشمام بقوله:

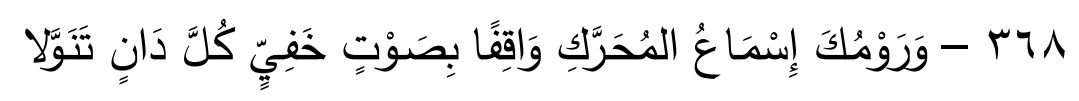

$$
\begin{aligned}
& \text { (') النشر في القراءات العشر (r/ צr (1) }
\end{aligned}
$$

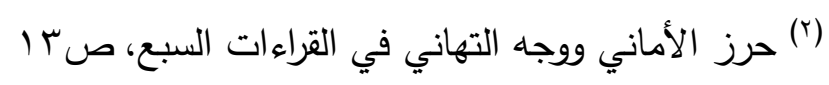

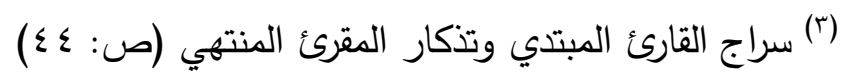




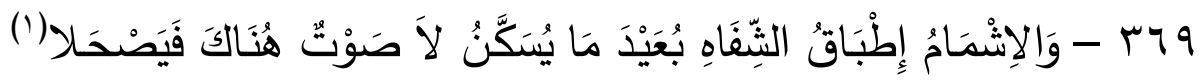

أفاد أنّ حقيقة الروم: أن يسمع القريب من القارئ حركة الحرف المحرك في الوصل بصوت خفي حال الوقف على هذا الحرف، وأما حقيقة الإشمام، فهي أن يطبق القـارئ شفتيه عقب تسكين الحرف، وذلك بـأن يجعل شفتيه على

صورتهما إذا انطقت بالحرف المضموم(؟).

وجاء عنه إطلاق الإشمام، وأراد به خلط حركة بحركة، كما في قوله:

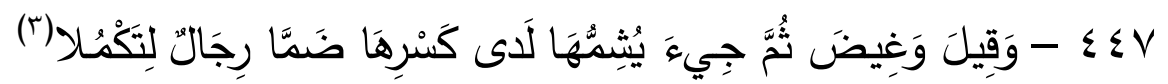

فالمقصود بالإشمام هنا خلط الضمة بالكسرة في هذه الأفعال (ء).

وكيفية الإشمام في هذه الأفعال أن تتحو بكسر أوائلها نحو الضمة، وبالياء بعدها نحو الواو، فهي حركة مركبة من حركتين كسر وضم، لأنّ هذه الأوائل

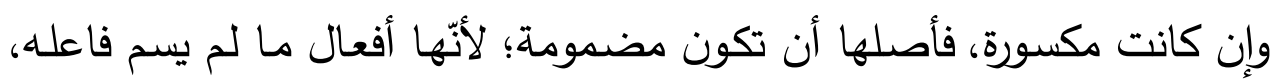
فأشمت الضم دلالة على أنّه أصل ما تستحقه، وهي لغة فاشية للعرب، وأبقوا شيئاً من الكسر تتبيها على ما تستحقه من الإعلال. (0)

$$
\begin{aligned}
& \text { (') حرز الأماني ووجه التهاني في القراءات السبع، ص. بـ } \\
& \text { (r) الوافي في شرح الثاطبية (ص: ع V V) }
\end{aligned}
$$

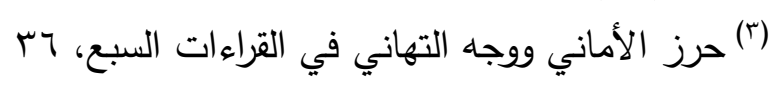

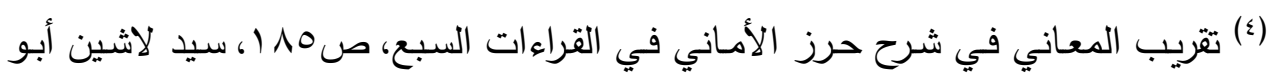

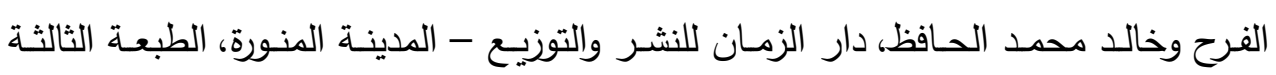

$$
\text { . }) \leqslant r \text {. }
$$

(0) سراج القارئ المبتدي وتذكار المقرئ المنتهي (ص: 9؛ () 
وجاء عنه أيضا إطلاق الإشمام وأراد به خلط حرف بحرف كما في قوله:

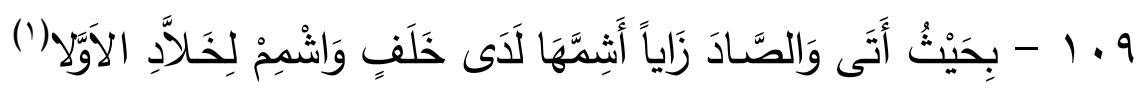

فالمراد بالإشمام في كلامه إشمام الصاد صوت الزاي أي خلطهما. (r) وطريقـة الإشـمام هنـا هـو : خلـط لفظ الصـاد بـالزاي، ومـزج أحـد الحـرفين بالآخر ، بحيث يتولد منهما حرف ليس بصـاد خالصـة، ولا بزاي خالصـة، ولكن

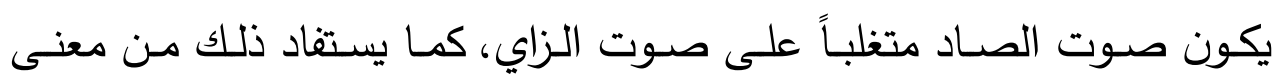
الإشمام، أو أن تتطق بالصاد كما ينطق العوام بالظاء (r). أما الاختلاس فقد ورد في نحو قوله:

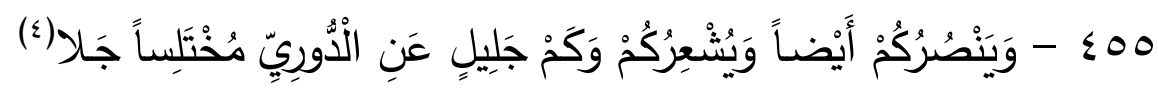

فالاختلاس في كلامه المقصود به إخفاء بعض الحركة والنطق بأكثرها. (•) وقد تقدم أنّه كان يطلق لفظ الإخفاء، ويريد به الاختلاس عند الحديث عن منهجه في الإخفاء عند النون الساكنة والتتوين.

(') حرز الأماني ووجه التهاني في القراءات السبع، صو (1)

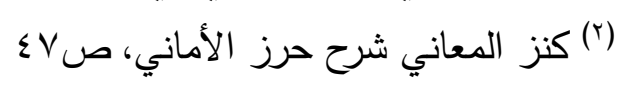

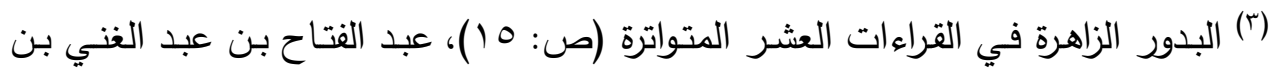
محمد القاضي (المتوفى: ب.ـ اهـ)، الناشر : دار الكتاب العربي، بيروت - لبنان

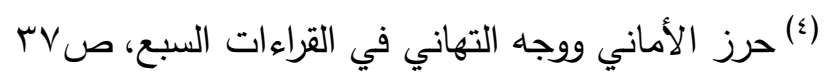
(0) فتح الوصيد في شرح القصيد، السخاوي، (1/9 ع ). 
فتبـين ممـا سـبق أن النـاظم - رحمـه - استعمل مصسطلح الروم والإشـمام والاختلاس وفق دلالاتهما المعروفة عند القراء، لكنه في بعض المواضـع أطلق الإشـمام، وأراد بـه خلط حركـة بحركة، كمـا أنـه أطلق الإشـام، وأراد بـه خلط حرف بحرف، و كثيراً ما كان يطلق على الاختلاس إخفاءاً. 


\title{
المبحث السابع
}

\section{منهج الإمام الثاطبي في استعمال الوقف والسكت}

\author{
الوقف لغة: الكف والحبس (').
}

اصطلاحا: قطع الصوت على الكلمة زمناً يتنفس فيه عادة بنية استئناف

$$
\begin{aligned}
& \text { القراءة، إما بما يلي الحرف الموقوف عليه، وإما بما قبله (广). } \\
& \text { السكت لغة: خلافُ النُّطْيَ وهو المنعَّ). }
\end{aligned}
$$

واصطلاحا: قطع الكلمة عما بعدها مقداراً قصيراً من الزمن قدر حركتين

دون تتفس، مع قصد العودة إلى القراءة فى الحال (ء).

وقد جاء مصطلح الوقف والسكت في نحو قول الناظم:

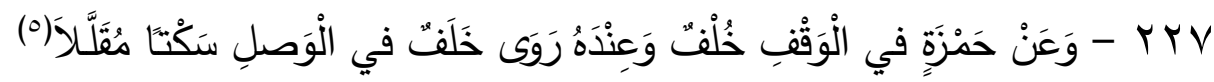

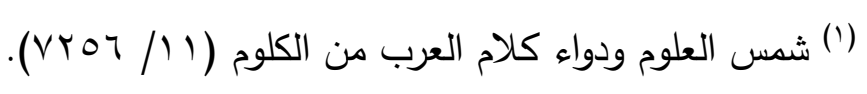

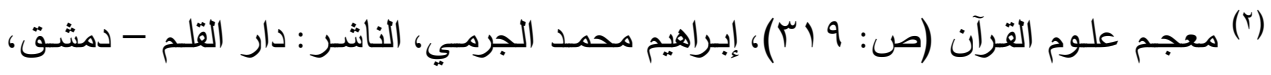

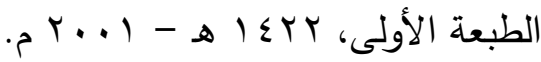

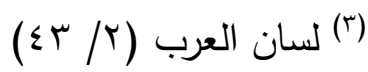

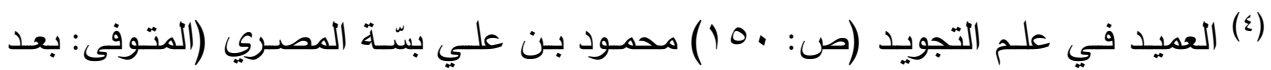

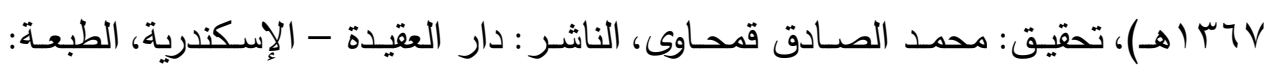

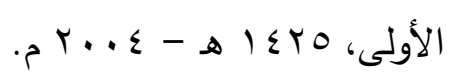

(0) حرز الأماني ووجه التهاني في القراءات السبع، صو 19 
فالمراد بالوقف الذي ذكره الوقف على الكلمة التي على الكلمة التي ينقل

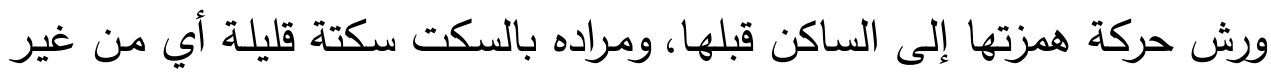

تنفس (')

وقد جاء عن الناظم - رحمه الله - توضيح السكت بقوله:

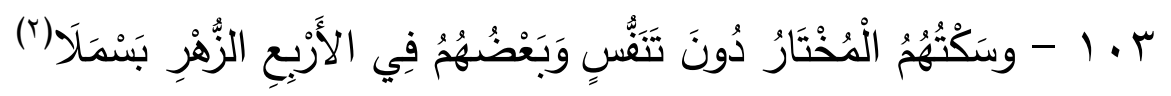

أي السكت بين السورتين دون تتفس أي من غير قطع نفس. (r)

فالناظم - رحمه الله - يستعمل السكت والوقف بمعناهما المعروف المشتهر

عند القراء.

$$
\text { (1) الوافي في شرح الثاطبية (ص: (1) (1) }
$$

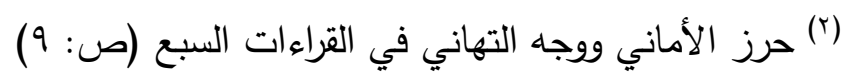

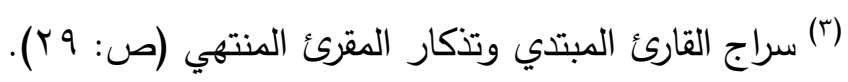




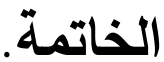

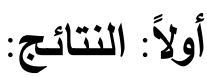

مما تقدم من دراسـة لمنهج الإمام الشاطبي في استعمال مصطلحات القراء يستتتج الباحث ما يلي: أنّ الناظم يستعمل التسهيل للدلالة علي معنيين هما: () إبدال الهمز حرف مد وتسهيلها بين بين r) مطلق التغيير في الهمز.

$$
-1
$$

ميز الناظم بين الترقيق والتفخيم فاستعمل للراءات التفخيم وللامات التغليظ، كما أنّه في موضع أطلق الترقيق وأراد به الإمالة وأطلق التفخيم وأراد بـه الفتح الذي هو عكس الإمالة. $-r$

في بعض المواضع استعمل المد وأراد به إثبات الألف واستععل القصر وأراد به حذف الألف وهذا كثير في نظمه. $-4$

ورد في نظمسه في مواضـع اسـتعمال الإخفـاء بمعنى الاخـتلاس، واسـتعمال

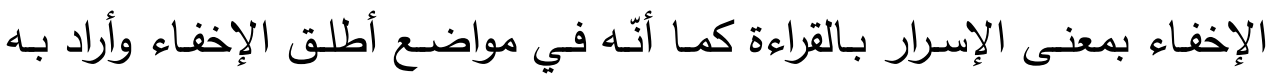
اختلاس حركة هاء الضمير . $-\varepsilon$ جاء في النظم في بعض المواضع إطلاق الإشمام بمعنى خلط حركة بحركة،

$$
\text { وبمعنى خلط حرف بحرف. }
$$




$$
\text { يوصي الباحث بما يلي: }
$$

دراسة منظومة الثاطبية للاستفادة منها في الجوانب العلمية التي حوتها.

$-Y$

تتبيه الدارسين لهذه المنظومة على اصطلاحات الإمام الثاطبي ومنهجه فيها

ليسهل استيعابها وفهمها.

$-4$

تشجيع البحوث العلمية التي تعنى بجانب القراءات ونشرها لتعم فائدتها. 


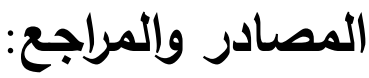

ا- إبراز المعاني من حرز الأماني في القراءات السبع، عبد الرحمن بن إبـراهيم بـن إسـاعيل المعـروف بأبي شـامة (المتـوفى 70 هـ)، تحقيـق: محمـود عبـدالخالق جـادو، مطـابع الجـامع الإســلامية بالمدينـة المنـورة ه

r- الإتقان في علوم القرآن، عبد الرحمن بن أبي بكر، جـلال الدين السيوطي (المتوفى: (19هـ)، تحقيق: محمد أبو الفضل إبراهيم، الناشـر :

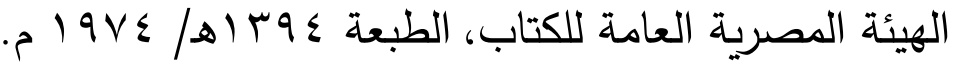
r- البدور الزاهرة في القراءات العشر المتواترة، عبد الفتاح بن عبد الغني بن محمد القاضي (المتوفى: ب • ـ اهـ)، الناشر : دار الكتاب العربي، بيروت - لبنان

ع- بغية المستفيد في علم التجويد، محمّد بن بدر الدين بن عبد الحق

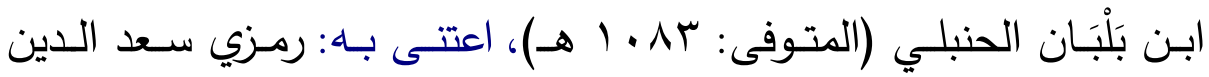
دمشقية، الناشر : دار البشائر الإسلامية للطباعة والنشر والتوزيع، بيروت -

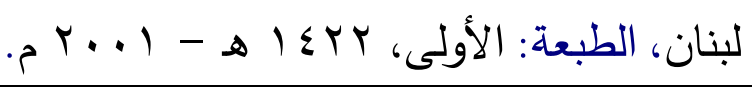
0- تاج العروس من جواهر القاموس، حمّد بن محمّد بن عبد الرزّاق الحسـيني، أبـو الفيض، الملقّب بمرتضـى، الزَّبِيدي (المتوفى: 0. ب اهـ)، تحقيق: مجموعة من المحققين، الناشر : دار الهداية 7- تاج العروس من جواهر القاموس، محمّد بن محمّد بن عبد الرزّاق الحسيني، أبـو الفيض، الملقّب بمرتضـى، الزَّبيدي، تحقيق : مجموعـة مـن المحققين، الناشر : دار الهداية. 
V - تقريـب المعـاني في شـرح حرز الأمساني في القراءات السبع، سيد لاشين أبو الفرح وخالد محمد الحافظ، دار الزمان للنشر والتوزيع - المدينة

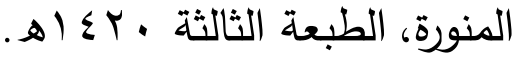

^- التمهيد في علم التجويد، شمس الدين أبو الخير ابن الجزري، محمد بـن محمد بـن يوسـف (المتوفى: بr/هـ)، تحقيـق: الدكتور على حسـين البـواب، الناشـر : مكتبـة المعـارف، الريـاض، الطبعـة: الأولى، 0 . 1 أهـ -

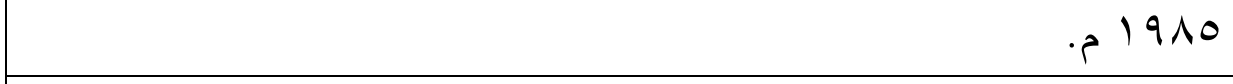
9- - التيسير في القراءات السبع، عثمان بن سـيد بن عثـان بـن عمر أبو عمرو الداني (المتوفى: ؟؟ §ه)، تحقيق: اوتو تريزل، الناشر : دار الكتاب العربي - بيروت، الطبعة: الثانية، ع • ع اهـ/ ع 9 ام. • 1- جمهـرة اللغــة، أبـو بكـر محمـد بـن الحسـن بـن دريـــ الأزدي (المتوفى: اYMه)، تحقيق: رمزي منير بعلبكي، الناشر : دار العلم للملايين 11 - حرز الأماني ووجه التهاني في القراءات السبع، القاسم بن فيره بـن خلف بـن أحمـد الرعيني الثـاطبي الأندلسـي المتوفى سـنة خمسـئة وتسعين هجريـة، ضبط وتصـيح: علي بن سعد الغامدي المكي، الطبعـة الأولى 0بـ ا هـ/ ع ا • بم، توزيع دار الغوثاني للدراسات القرآنية - دمشق - سورية.

r ا- سراج القارئ المبتدئ وتذكار المقرئ المنتهي، أبو القاسم علي بن عثمان بن محمد بن أحمد بن الحسن القاصح العذري البغدادي من علماء القرن التاسـع الهجري، طبع شركة ومطبعة مصطفى البابي الحلبي وأولاده 
با - شـرح طيبـة النشـر لابـن الجزري، شـس الدين أبـو الخيـر ابـن الجزري، محمد بن محمد بن يوسف (المتوفى: سبهـه)، ضبطه وعلق عليـه: الثـيخ أنس مهـرة، الناشـر : دار الكتب العلميـة - بيـروت، الطبعـة:

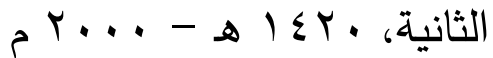

§ ا- شـس العلـوم ودواء كـلام العـرب مـن الكلـوم، نشـوان بـن سـعيد الحميرى اليمني (المتوفى: سمهـ)، تحقيق: د حسين بن عبد الله العمري مطهر بـن علي الإريـاني - د يوسف محمد عبد الله، الناشـر : دار الفكر المعاصر (بيروت - لبنان)، دار الفكر (دمشق - سورية)، الطبعة الأولى، . 1999- ه 1 1 14 .

10- الصـحاح تـاج اللغـة وصـحاح العربيـة، أبـو نصـر إسـماعيل بـن حمـاد الجـوهري الفـارابي (المتـوفى: سوسهـ)، تحقيـق: أحمـد عبـد الغفور

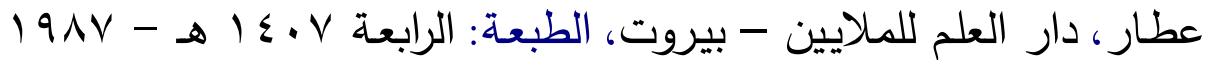

7 ا- - العميد في علم التجويد، محمود بن علي بسّة المصري (المتوفى:

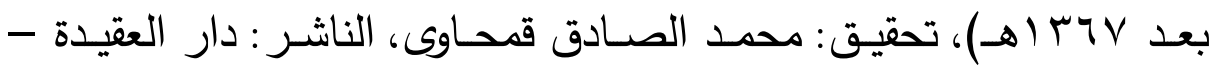

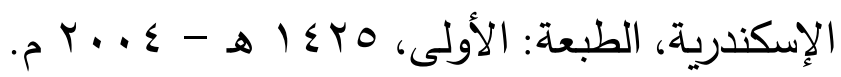

IV الفراهيدي البصـري (المتـوفى: • V Vهـ)، تحقيـق: د مهـدي المخزومسي، د إبراهيم السامرائي، الناشر : دار ومكتبة الهلاله. 11 - غاية المريد في علم التجويد، عطية قابل نصر، الناشر : القاهرة، 


\begin{tabular}{|c|}
\hline السابعة . \\
\hline 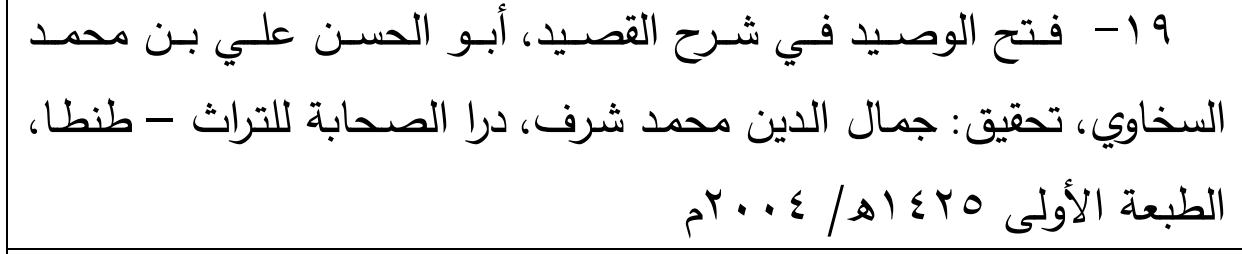 \\
\hline 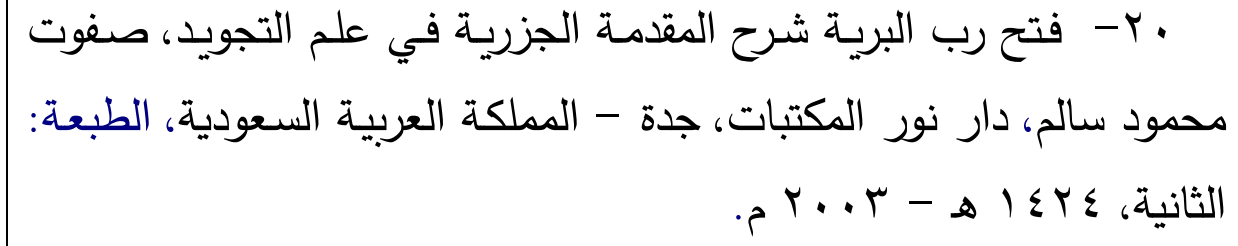 \\
\hline 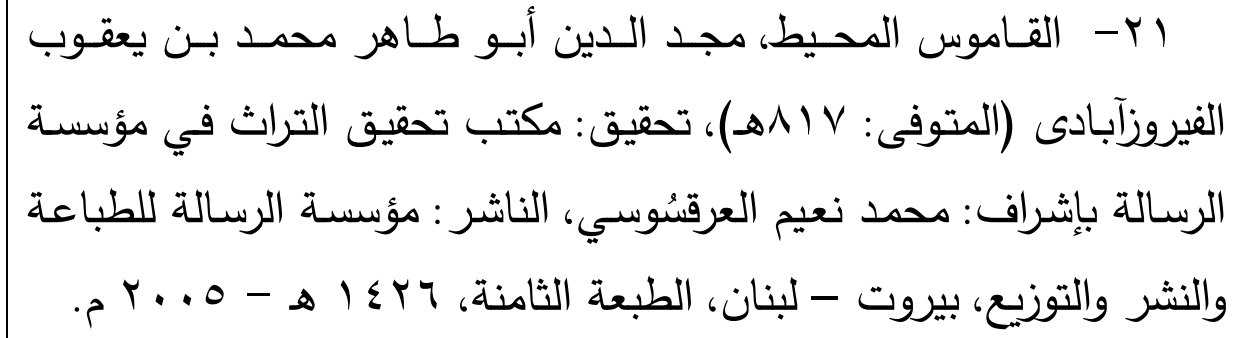 \\
\hline 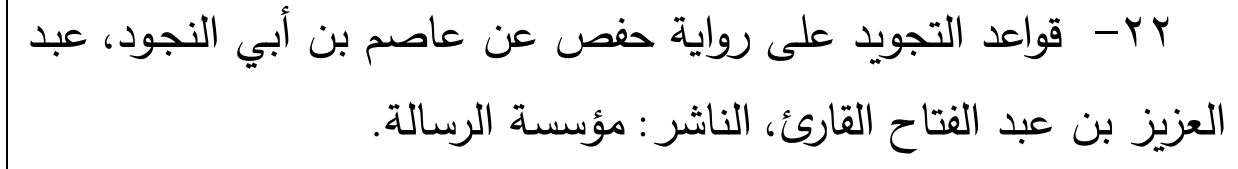 \\
\hline 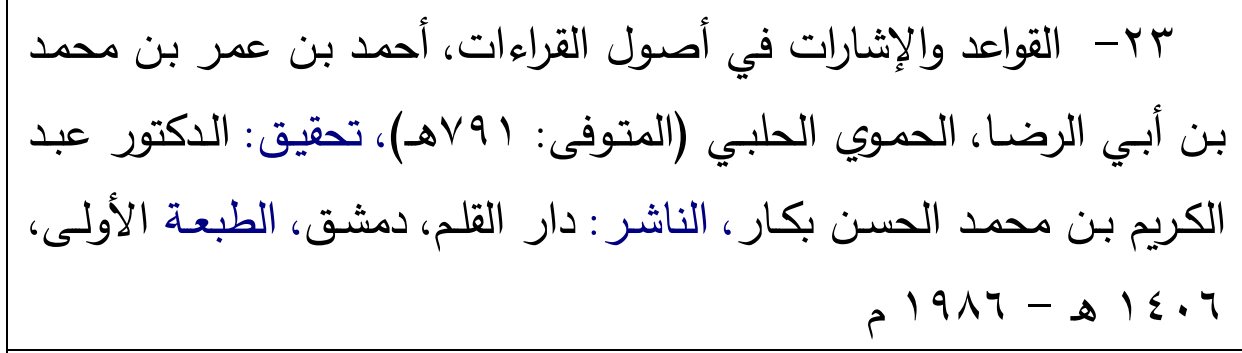 \\
\hline 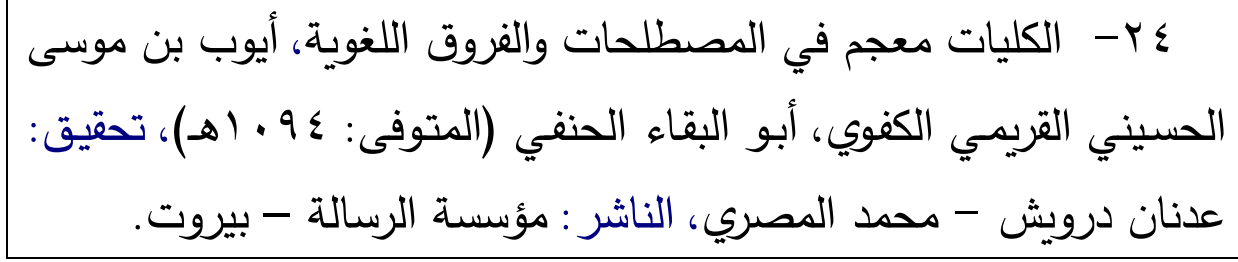 \\
\hline
\end{tabular}


هr- كنز المعاني شرح حرز الأماني، أبو عبدالله محمد بن أحمد بن محمد بن أحمد بن الحسين الموصلي المعروف بشعلة المتوفى سنة ستمائة وست وخمسين هجريـة، تحقيق: الشيخ زكريـا عميرات، الطبعـة الثانية، دار الكتب العلمية - بيروت لبنان.

צr - لسان العرب، محمد بن مكرم بن على، أبو الفضل، جمال الدين ابن منظور الأنصاري الرويفعى الإفريقى (المتوفى: Iالهـ)، الناشر : دار

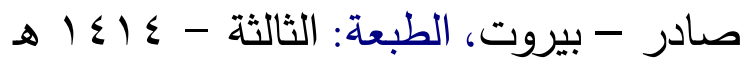
- rV عبد القادر الحنفي الرازي (المتوفى: 777 هـ)، تحقيق: يوسف الثيخ محمد، الناشـر : المكتبـة العصـريـة الـدار النموذجيـة، بيـروت - صـيدا، الطبعـة

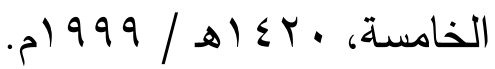

^ץ - مختصر العبارات لمعجم مصطلحات القراءات، إبراهيم بن سعيد بـن حمــ الدوسـري، الناشـر : دار الحضـارة للنشـر - الريـاض - المملكـة

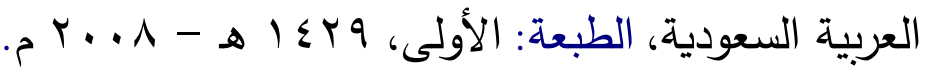
qr - المعجم الوسيط، مجمع اللغة العربية بالقاهرة، (إبراهيم مصطفى / أحمد الزيات / حامد عبد القادر / محمد النجار)، الناشر : دار الدعوة. - "r- معجم علوم القرآن، إبراهيم محمد الجرمي، الناشـر : دار القلم .

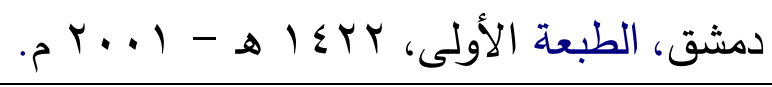
اس- معجم لغـة الفقـهء، محمد رواس قلعجي - حامد صـادق قنيبي، الناشر : دار النفائس للطباعة والنشر والتوزيع، الطبعة الثانية، 1 ـ ـ ا هـ ـ ? 1911 
rr- معجم مقاييس اللغة، حمد بن فارس بن زكرياء القزويني الرازي، أبو الحسين (المتوفى: 9 بهـ)، تحقيق: عبد السـلام محمد هارون، الناشر :

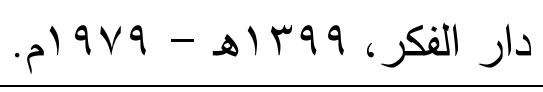

سب- مقدمـات في علم القراءات، محمد أحمـد مفلـح القضـاة، وأحمد خالد شكرى، ومحمد خالد منصور، الناشر : دار عمار - عمان (الأردن)،

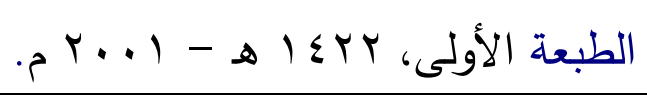

ع - النشر في القراءات العشر، شمس الدين أبو الخير ابن الجزري، محمـد بـن محمـد بـن يوسـف (المتـوفى: سبر هـ)، تحقيـق: علي محمــ الضباع (المتوفى •^ر ا هـ)، الناشـر : المطبعـة التجاريـة الكبرى [تصـوير دار الكتاب العلمية]. هr- الوافي في شرح الثاطبية، عبدالفتاح القاضي، درا السلام للطباعة والنشر والتوزيع، الطبعة السادسة . بـ ا- . . بم. 